\title{
Price Adjustments on Ex-Right Dates in Cases of Right Offerings
}

\author{
Pyung Sig Yoon ${ }^{* *}$, Professor, Chungnam National University
}

\begin{abstract}
$\langle$ Abstract $\rangle$
Using a sample of 618 right offerings made between 2004 and 2016, this study analyzes price adjustments on ex-right dates. The major results are as follows. First, as the ratio of reference price divided by the ex-right opening price is calculated as 0.9613 , price adjustments are significantly less than the value of preemptive rights. We also document additional price decreases after ex-right dates. The smaller price drops on ex-right dates and delayed adjustments are evidence of market inefficiency. Second, the listing of preemptive rights certificates makes price adjustments on ex-right dates more efficient. Third, the abnormal return on ex-right dates is $4.24 \%$, which is significantly positive. Fourth, the trading strategies of purchasing at cum-right prices, selling at ex-right prices, and purchasing new shares generate a $2.59 \%$ return, and foreign investors are most likely to follow such trading strategies. In addition, for the fourth quartile, which has the largest preemptive rights value, the abnormal return on ex-right dates is $9.31 \%$, and the trading strategy generates a $5.77 \%$ return. In summary, although the Korea Exchange discloses a reference price for efficient adjustment, price adjustment on ex-right dates is not efficient, thus generating profitable investment opportunities. Significant abnormal returns owing to inefficient price adjustments on ex-right dates are partly consistent with anchoring biases.
\end{abstract}

Keywords: Right Offerings; Price Adjustment on Ex-Right Date; Preemptive Right Value; Market Efficiency; Anchoring Bias

JEL Classification: G14, G32, G38

\footnotetext{
* We are grateful for comments from two anonymous referees.

** Corresponding Author. Address: Chungnam National University, School of Business, 99 Daehak-ro, Yuseong-gu, Daejeon, Korea 34134; E-mail: psyoon@cnu.ac.kr; Tel: +82-42-821-5540; +82-42-821-8718.
}

Received: July 18, 2019; Revised: November 11, 2019 \& December 26, 2019; Accepted: January 9, 2020 


\title{
주주배정방식 유상증자의 권리락일 주가조정에 관한 연구
}

윤 평 식 (충남대학교 교수) ${ }^{* *}$

\begin{abstract}
본 연구는 2004년부터 2016년까지 공시된 주주배정 유상증자 618건을 대상으로 권리락일의 주가조정을 분석하며 주요 결과는 다음과 같다. 첫째, 기준가격을 권리락시가로 나눈 비율인 신주인수권가치 반영비율이 0.9613 으로 산출되는데 이는 권리락일에서의 주가조정이 신주인수권의 가치보다 작게 이루어짐을 의미한다. 또한 권리락일에 주가가 덜 하락할수록 차후에 주가가 더 많이 하락하는 것으로 나타난다. 신주인수권가치 과소반영과 지연현상은 시장의 비효율성을 의미한다. 둘째, 신주인수권증서의 상장제도는 권리락일의 주가조정이 보다 효율적으로 이루어지는데 기여한다. 셋째, 권리락일에서의 초과수익률은 $4.24 \%$ 로 매우 유의적이다. 넷째, 권리부가격에 매입하고 권리락가격에 매도하여 신주를 배정받는 거래전략으로 투자자는 $2.59 \%$ 의 수익률을 얻을 수 있으며, 외국인투자자가 '권리부매입 권리락매도'의 패턴을 보인다. 다섯째, 신주인수권의 가치가 클수록 주가조정이 더 작게 이루어지며, 신주인수권의 가치가 가장 큰 쿼타일의 경우 권리락일의 초과수익률이 $9.31 \%$ 이고 거래전략의 수익률은 $5.77 \%$ 이다. 요약하면, 거래소는 효율적인 주가조정을 위해 기준가격을 공시하지만, 실제로 권리락일 에서의 주가조정이 효율적으로 이루어지지 않으며 이로 인해 투자기회가 발생한다. 권리락일의 비효율 적인 주가조정으로 인해 초과수익률이 발생하는 현상은 부분적으로 앵커링 편의로 설명된다.
\end{abstract}

핵심 단어 : 주주배정 유상증자, 권리락일 주가조정, 신주인수권의 가치, 시장효율성, 앵커링 편의

JEL 분류기호: G14, G32, G38

* 본 논문에 대해 유익한 조언을 해 주신 두 분 익명의 심사자께 감사의 말씀을 드립니다.

** 연락담당 저자. 주소: 대전광역시 유성구 대학로 99 , 충남대학교 경상대학 경영학부, 34134 ; E-mail: psyoon@cnu.ac.kr; Tel: 042-821-5540; Fax: 042-821-8718. 


\section{1. 서론}

유상증자(seasoned equity offerings)는 신주를 새로 발행하여 시설 및 운영자금을 조달하는 방법으로 상장기업의 가장 중요한 자금조달 방법의 하나이다. 유상증자의 방식에는 크게 주주 배정방식, 일반공모방식, 제 3 자배정방식이 있다. 미국의 경우 일반공모방식이 가장 보편적으로 이용되지만 우리나라의 경우 일반공모방식은 외환위기 직후인 1997년 말에, 선진화된 자금조달 방법을 도입하고 외국인 투자자의 참여를 적극 유도하기 위하여 처음 도입되었으며 최근 들어 주주배정방식보다 더 많이 이용되고 있다(Yoon, 2016b). 제3자배정은 건수 및 금액 기준으로 가장 많이 이용되는 방식이지만 주로 사모로 발행되어 여러 유형의 불공정거래의 수단으로 악용되고 있어 그동안 재무 분야의 연구에서 소외되었다.1)

미국의 경우 일반공모가 가장 많이 이용되므로 일반적으로 유상증자에 관한 연구는 일반공모 방식으로 제한되며, right offering 과 private placement는 따로 분석한다. 그러나 우리나라의 경우 표본을 방식별로 구성하는 경우는 매우 드물고, 대부분 주주배정방식과 일반공모방식을 혼용하여 표본을 구성하고, 때로는 세 가지 방식을 모두 이용하여 표본을 구성하기도 한다.

세 가지 발행방식은 발행방법(공모 vs 사모), 공시효과(긍정적 vs 부정적), 발행가격 결정과정, 발행 이유, 최대주주의 입장 등 여러 가지 측면에서 상이하다. 우리나라에서 최근의 연구는 일관성 있게, 주주배정방식과 일반공모방식의 유상증자가 공시되면 공시효과가 유의적인 음이라고 보고한다.2) 반면에 사모로 발행되는 제3자배정방식의 유상증자는 유의적인 주가상승을 야기 한다고 보고한다.3) 또한, Kim et al.(2014)은 수익성과 재무건전성이 높지 않을 경우 주주배정 방식보다 일반공모방식을 선택할 가능성이 높다고 주장한다. 그리고 Yoon(2016a)도 미래에 주가가 상승할 것으로 예상하는 최대주주가 신주에 대한 권리를 포기할 가능성이 낮으므로 경영자가 주주배정 방식 대신에 일반공모방식을 선택하게 되면 이는 경영자의 미래에 대한 부정적인 인식을 시장에 전달할 수 있다고 주장한다.

주주배정 방식은 위에서 언급한 이유 이외에도 권리락일에 주가조정이 이루어진다는 면에서 그리고 신주인수권(preemptive right)이 상장되어 거래된다는 점에서 일반공모 및 제3자배정과 차별화된다. Yoon(2019)은 주주배정 유상증자에 의해 상장된 신주인수권증서(preemptive right

1) Kim and Moon(2010)은 제 3 자배정이 불공정거래에 따른 주가급등락, 한계기업의 시장퇴출 회피수단, 편법 자금조달 및 머니게임 수단으로 악용되는 문제점을 제시한다.

2) Yoon(2016b)은 1991년부터 2013년까지의 일반공모와 주주배정 방식의 유상증자 공시효과를 분석한 결과 1991년부터 2001년까지는 공시효과가 양이지만 2002년 이후의 공시효과는 음이라고 보고한다. 즉, 3 일간 누적초과수익률이 전반기에는 $1.56 \%$ 이지만 후반기에는 $-6.56 \%$ 로 보고한다.

3) 참고로 미국의 경우 일반공모방식은 유의적인 음의 공시효과를, 주주배정방식의 경우 비유의적인 음의 공시효과를, 그리고 제 3 자배정방식의 경우 양의 공시효과를 가져오는 것으로 알려져 있다. 최근의 일반공모 공시효과는 Kim and Purnanandam(2014)을 참고하고, 주주배정방식의 경우 Eckbo and Masulis(1995)를 참고하라. 제3자배정방식의 경우에는 Wruck(1989), Hertzel and Smith(1993), Barclay et al.(2007)을 참고하라. 
Price Adjustments on Ex-Right Dates in Cases of Right Offerings

certificate) 257건을 대상으로 차익거래 가능성을 분석한 결과, 주식을 공매도함과 동시에 신주인수권증서를 매입하는 신주인수권증서 차익거래로 1 개월 조금 넘는 기간 동안 $9.70 \%$ 의 수익률(연 기준 $95.69 \%$ )을 얻을 수 있는데 이는 신주인수권증서가 시장에서 과소평가됨을 의미한다고 보고한다.

유사한 맥락에서 본 연구는 주주배정방식 유상증자만을 대상으로 권리락일(ex-right date)의 주가조정과 투자기회를 검증한다. 권리락일에서의 주가조정은 거래소가 권리락일의 기준가격을 미리 공시한 상황에서 주가조정이 이루어지는 것이므로 주식시장의 효율성을 검증하는 효과적인 방법이 되며 또한 효율적으로 주가조정이 이루어지지 않으면 투자기회를 제공할 수도 있다. Kang and Stulz(1996)와 McGuinness(2001)는 각각 일본과 홍콩의 유상증자 권리락일의 주가조정을 분석한 결과 권리락일에 초과수익률이 발생하지 않는다고 보고한다. 그러나 Goyal et al.(1994)과 Bolognesi and Gallo(2013)는 각각 일본과 이탈리아의 경우 유의적인 양(+)의 권리락일 초과수익률을 보고한다.

만약 권리락일에 주가조정이 효율적으로 이루어지지 않으면 두 가지 투자전략이 가능하다. 첫 번째 전략은 신주인수권증서가 상장되지 않는 경우에 취하는 포지션으로, 권리부가격에 주식을 매입하고 권리락가격에 매도하여 신주인수권을 획득하고 이후 발행가격을 납입하고 신주를 배정받아 매도하는 것이다. 두 번째 전략은 신주인수권증서가 상장되는 경우에 취하는 포지션으로 권리부가격에 주식을 매입하고 이를 권리락가격에 매도한 후 획득한 신주인수권 증서를 매도하는 것이다.4)

신주인수권증서의 상장은 여러 긍정적인 기능을 수행한다.5) 첫째, 유상증자에 참여하기를 꺼리는 주주는 신주인수권증서를 매도함으로써 금전적 손실없이 자기의 목적을 달성할 수 있다. 둘째, 주식공매도자가 신주인수권을 원소유자에게 반환할 수 있어 권리락일 이후까지 공매도 포지션을 연장할 수 있도록 함으로써 시장의 효율성에 기여한다. 셋째, 신주인수권증서의 거래를 통해 새로운 투자기회를 제공한다. 넷째, 신주인수권증서와 주가 간에 균형관계가 성립하며 이 관계가 성립되지 않으면 차익거래기회가 발생한다. 다섯째, 비주주에게 주식을 매입할 수 있는 새로운 기회를 제공한다. 따라서 신주인수권증서의 상장제도가 도입됨에 따라 권리락일에서의 주가조정이 보다 효율적으로 이루어질 개연성이 존재하므로 본 연구에서는 신주인수권증서가 상장되지 않은 유상증자와 증서가 상장되는 유상증자를 구분하여 권리락일에서의 주가조정에서 두 그룹간에 차이가 나는지 검증하고자 한다.

본 연구는 2004년부터 2016년까지 공시된 주주배정 유상증자 618건(코스피 132건, 코스닥 486건)을 대상으로 권리락일의 주가조정을 분석한다. 중요한 분석 결과는 다음과 같다. 첫째,

4) 신주인수권증서가 최초로 상장된 유상증자는 2002년 5월 7일에 공시된 신성이엔지의 유상증자이다. 신주인수권증서의 상장이 일정 기간 권고사항이었으나 2013년 5월 28일 자본시장과 금융투자업에 관한 법률 제 165 조가 개정됨에 따라 이후 실시되는 주주배정방식 유상증자의 경우 신주인수권증서의 상장이 의무화되었다(Yoon, 2019, 352쪽).

5) 이 부분은 Yoon(2019)의 논문을 참고하여 신주인수권증서의 상장이 미치는 긍정적인 역할을 요약한 것이다. 
한국증권학회지 제49권 3호 (2020)

권리락일에 신주인수권의 가치만큼 주가조정이 발생한다면 권리락시가가 기준가격과 동일해야 하는데, 분석 결과 기준가격을 권리락시가로 나눈 비율(즉, 신주인수권가치 반영비율)이 0.9613 으로 $1 \%$ 신뢰수준에서 1 과 동일함을 기각할 수 있다. 이는 주가조정이 신주인수권의 가치보다 유의적으로 작게 이루어짐을 의미한다. 또한 권리락일에 주가가 덜 하락할수록 차후에 주가가 더 많이 하락하는 것으로 나타난다. 신주인수권가치 과소반영과 지연현상은 시장의 비효율성을 의미한다. 둘째, 신주인수권의 가치를 기준으로 4 개의 쿼타일(quartile)로 나누어 분석한 결과, 신주인수권의 가치가 클수록 권리락일에서의 주가조정이 더 작게 이루어지며(즉, 신주인수권가치 반영비율이 감소함) 또한 권리락일 이후부터 신주상장일까지의 주가하락이 크다. 셋째, 권리락일 에서의 초과수익률은 첫 번째 결과와 일관성있게 $4.24 \%$ 이고 $(\mathrm{t}-\mathrm{value}=16.38)$ 권리락일부터 +3 일까지의 $\operatorname{CAR}(0,3)$ 는 $5.73 \%$ 이다. 넷째, 권리부가격에 매입하고 권리락가격에 매도한 후 신주를 배정받는 거래전략을 시행하면(투자기간 51 일) 투자자는 $2.59 \%$ 의 수익률을 얻는다. 또한 신주인수권의 가치가 클수록 주가조정이 더 작게 이루어지므로 신주인수권의 가치가 가장 큰 쿼타일의 경우 권리락일의 초과수익률이 $9.31 \%$ 이고 거래전략의 수익률은 $5.77 \%$ 이다. 다섯째, 개인투자자는 '권리부매도 권리락매수'의 패턴을 보이고 외국인투자자는 '권리부매입 권리락 매도'의 패턴을 보인 반면에 기관투자자는 특정한 패턴을 보이지 않는다. 여섯째, 신주인수권 증서의 상장제도는 권리락일 주가조정의 비효율성을 완화하는데(또는 감소시키는데) 기여한다. 즉, 신주인수권증서가 상장되는 유상증자와 상장되지 않은 유상증자를 구분하여 권리락일에서의 신주인수권가치 반영비율을 비교한 결과, 신주인수권증서의 상장제도가 도입된 이후 신주인수권 가치 반영비율이 유의적으로 증가한다.

권리락일의 비효율적인 주가조정으로 인해 초과수익률이 발생하는 현상은 부분적으로 앵커링 편의로 설명된다(Chang et al., 2019). 앵커링 편의는 의사결정시 앵커라고 불리는 특정 값(본 연구에서는 권리부가격)에 의해 영향을 받는 심리적 편의이다.

본 연구는 신주인수권의 가치가 과소평가된다는 점에서 Yoon(2019)의 연구와 맥락을 같이 한다. 그러나 본 연구는 권리락일의 주가조정을 최초로 분석하였으며, 권리락일에서의 주가조정이 신주인수권의 가치보다 작게 이루어질 뿐만 아니라 조정이 지연되는 지연현상이 발생함으로써 '시장의 비효율성'을 발견한다는 점에서 의의가 있다. 권리락일의 주가조정이 효율적으로 이루어 지지 않음으로 인해 투자기회가 발생하며, 특히 신주인수권가치가 큰 쿼타일의 경우 주가조정이 매우 비효율적으로 이루어지므로 거래전략으로 보다 높은 수익률을 실현할 수 있다. 또한 신주인수권 증서의 상장제도가 권리락일 주가조정에서 나타나는 비효율성을 완화하는 중요한 결과도 추가로 보고한다. 요약하면, 본 연구는 권리락일 주가조정의 비효율성과 이에 따른 투자기회뿐만 아니라 신주인수권증서의 상장제도가 권리락일 주가조정에 미치는 효과를 최초로 제시한다는 점에서 재무이론에 공헌한다고 사료된다.

본 논문의 구성은 다음과 같다. 먼저 제 2장에서 선행연구를 요약하고, 제 3장에서 표본구성, 방법론, 주주배정 방식 주요일정을 소개하기로 한다. 실증 결과는 제 4 장에 제시되어 있으며 제 5장에서 결론을 도출하기로 한다. 


\section{2. 선행 연구 요약}

우리나라에서 유상증자에 관한 연구는 일반공모와 주주배정 방식을 위주로 진행되었다. Yoon (2016b)은 1991년부터 2013년까지 23년 동안 공시된 유상증자(일반공모와 주주배정방식) $3,161$ 건을 분석한 결과, 1991 년부터 2001 년까지는 공시효과가 양이지만 $\operatorname{CAR}(0,2)=1.56 \%)$ 2002 년부터 음으로 전환된다고 보고한다 $(\mathrm{CAR}(0,2)=-6.56 \%)$. 이유는 후반기에 유상증자를 실시한 기업은 전반기 기업에 비하여 영업성과가 낮고 영업현금흐름도 부족하며 상대적으로 부채비율이 높으며 또한 조달한 금액 중 자본적 지출과 연구개발비에 투자하는 비율도 유의적으로 낮은 재무곤경기업이기 때문이라고 주장한다. 또한 Lim and Yoon(2017)은 일반공모와 주주배정 방식 1,049 건 유상증자 공시 전후의 거래행태를 분석한 결과, 기관투자자는 공시일 이전에 순매도하는데 이는 기관투자자가 유상증자 공시전에 정보를 사전 취득하여 투자의사결정에 활용한다고 추론한다.

세 방식을 통합하여 표본을 구성하여 분석하기도 한다. 예를 들어, Kim and Byun(2016)은 방식 구별 없이 표본을 구성한 후 대주주의 지분율이 증가하는 유상증자 공시일 전후의 누적초과수익률 $(\mathrm{CAR})$ 은 대주주의 지분율이 감소하는 유상증자의 누적초과수익률보다 높다고 보고한다.

반면에 최근 유상증자 방식별로 연구가 진행되는 경향이 있다. Yoon(2016a)은 777건의 일반공모방식 유상증자만을 분석한 결과, 777 건의 $44 \%$ 가 3 년 이내에 상장폐지된 기업에 의해 발행되며 소액공모가 절반 이상을 차지한 결과 공시일부터 상장 후 1 년까지 누적초과수익률이 $-45 \%$ 라고 보고한다. 미국의 경우 여러 연구가 일반공모 유상증자의 부정적 공시효과에 대해 일관성있는 결과를 제공하는데 최근의 연구인 Kim and Purnanandam(2014)도 4,613건 유상증자의 2일간 누적초과수익률이 $-1.97 \%$ 로 보고한다(표본기간은 1982년부터 2006까지임). Lim et al.(2019)은 제3자배정 1,796건을 분석한 결과 3일간의 누적초과수익률이 $7.14 \%$ 라고 보고하며 양의 공시효과는 모니터링가설과 보증가설을 지지한다고 주장한다.

요약하면, 우리나라에서 일반공모와 주주배정 방식의 경우 공시효과가 부정적인데 반하여, 제3자배정방식의 경우 공시효과는 미국과 유사하게 긍정적이다.6) Kim, et al.(2019)은 공시일 전후 3 일 $\mathrm{CAR}$ 이 주주배정방식의 경우 $-4.90 \%$ 이고 일반공모방식의 경우 $-3.53 \%$ 이고 제 3 자 배정의 경우 $5.58 \% \sim 14.28 \%$ 라고 보고한다.

또한 Yoon(2019)과 Yoon and Lim(2018)은 주주배정방식만을 대상으로 분석하였다. Yoon (2019)은 주주배정 유상증자에 의해 2011년부터 2016년까지 한국거래소에 상장되어 거래된 신주인수권증서(preemptive right certificate) 257건을 분석한 결과, 신주인수권증서가 거래되는

6) 비교적 최근에 진행된 연구에서도 양의 공시효과가 보고되기도 한다(Chung and Jeong, 2008; Yoon et al., 2013; Kim and Byun, 2016). 이유는 일반공모와 주주배정 방식뿐만 아니라 제3자배정방식도 포함하기 때문으로 판단한다. 우리나라 제 3 자배정의 공시효과가 양으로 매우 유의적이므로 분석에 공시효과를 이용하는 경우 반드시 제 3 자배정방식을 제외하거나 또는 증자 방식을 분석에 반영하여야 한다. 
한국증권학회지 제49권 3호 (2020)

기간 동안 주식을 공매도함과 동시에 신주인수권증서를 매입하는 신주인수권증서 차익거래로 1 개월 조금 넘는 기간 동안 $9.70 \%$ 의 수익률(연 기준 $95.69 \%$ )을 얻을 수 있는데 이는 신주인수권 증서가 시장에서 과소평가되었기 때문이라고 주장한다. Yoon and Lim(2018)은 2009년부터 2015년까지 공시된 주주배정방식 91건의 공매도 거래를 분석한 결과 유상증자 공시일부터 최종발행가격 확정일까지의 기간 동안에는 비정상 공매도 거래가 발생하며 비정상 공매도 거래가 발행가격 하락에 유의적인 영향을 미치는 것으로 보고한다.

한편, 본 연구가 분석하는 권리락일의 주가조정과 유사한 주제가 배당락일의 주가조정이다. 배당락일의 주가조정에 관한 연구는 Woo(1993), Kim(1997), Yoon et al.(1998), Park and Park(2011), Kim and Choi(2016), Khil and Han(2018) 등에 의해 이루어졌다. Yoon et al.(1998)은 1992년부터 1995년까지 실시된 현금배당 1,396건을 대상으로 배당락일의 주가조정 모형을 검증한 결과, 금기배당금을 이용한 주가하락비율은 1.342 로 이론적인 주가하락비율인 0.785보다 크게 나타났는데, 이유는 투자자가 미래 배당금을 모른 상태에서 전기 배당금을 금기배당금의 추정치로 사용하여 주가조정을 하기 때문이라고 한다.7) 또한 Jung et al.(2002)은 무상증자와 주식배당을 중심으로 배당락일과 권리락일의 주가조정에 반영된 세금효과를 분석하였다.

배당락일의 주가조정과 유상증자 권리락일의 주가조정은 두 가지 측면에서 상이하다. 첫째, 우리나라의 경우 배당락일이 배당결정일보다 앞서므로 효율적인 주가조정이 이루어지기 어렵다. 그러나 주주배정 방식 유상증자의 경우 거래소가 주가조정이 효율적으로 이루어지도록 돕기 위하여 권리락일에서의 주가조정에 필요한 기준가격을 사전에 공시한다. 둘째, 배당락일의 주가조정은 배당소득세율과 자본소득세율에 의해 결정되는데, 권리락일의 주가조정은 세금과 연관되어 있지 않다. 그러나 배당락일의 주가조정과 유상증자 권리락일의 주가조정이 모두 시장의 효율성을 측정할 수 있는 하나의 방법이 되는 것은 공통점이다.

주주배정 유상증자의 권리락일에서의 초과수익률에 대한 분석은 일본의 경우 Kang and Stulz(1996)와 Goyal et al.(1994), 홍콩의 경우 McGuinness(2001), 그리고 이탈리아의 경우 Bolognesi and Gallo(2013)에 의해 이루어졌다. Kang and Stulz(1996)는 1985년부터 1991년 까지 일본에서 공시된 주주배정방식 28건의 경우 권리락일에서의 초과수익률이 비유의적이라고 보고한다. 반면에 Goyal et al.(1994)은 1975년부터 1989년까지 주주배정 유상증자를 공시한 동경주식거래소 주식 248 개를 대상으로 분석한 결과 권리락일에서의 초과수익률이 $7.10 \%$ 로 양으로 유의적이라고 보고하며 여러 가능한 이유를 검증하였지만 설득력있는 설명이 가능하지 않다고 보고한다. McGuinness(2001)는 홍콩의 주식을 대상으로 분석한 결과 권리락일에 초과수익률이 발생하지 않는다고 보고한다. 그리고 Bolognesi and Gallo(2013)는 2007년 1 월부터 2011년 4월까지 공시된 이탈리아주식거래소 주주배정 유상증자 70 건을 분석한 결과 권리락일에서의 초과수익률이 $5.85 \%$ 라고 보고한다.

7) 주가하락비율은 배당부종가에서 배당락시가를 차감한 후 이를 주당배당금으로 나눈 비율이다. 이론적 으로 이 비율은 배당소득과 자본이득에 대한 세율에 의해 결정되며 그 당시 세율에 의하면 0.785 이다. 
Price Adjustments on Ex-Right Dates in Cases of Right Offerings

유사한 연구로 주식분할일의 초과수익률에 대한 연구가 있다. Hwang and Shin(2007)은 2000년부터 2007년까지 공시된 주식분할(stock split) 131건을 분석한 결과, 공시일의 초과수익률이 양으로 유의적이고 $(\mathrm{AR}=3.18 \%, \mathrm{t}-\mathrm{value}=4.36)$, 분할일 $($ 신주상장일 $)$ 에서의 초과수익률은 양이지만 유의적이지 않다고 보고한다 $\left.(\mathrm{AR}=1.13 \%, \mathrm{t}-\mathrm{value}=0.74) .{ }^{8}\right)$ 주식분할의 경우에도 분할일 전일에 발행기업이 분할일이 언제이며 기준가격이 얼마인지 공시한다. Maloney and Mulherin(1992)도 주식분할일에 수익률이 $1.64 \%$ 이며 분할일부터 +2 일까지의 수익률이 $2.24 \%$ $(\mathrm{t}-\mathrm{value}=7.42)$ 라고 보고한다. 주식 분할일 초과수익률의 경우에는 분할 이후 주식의 유동성이 크게 영향을 받는다는 측면에서 유상증자 권리락일에서의 주가조정(또는 초과수익률)의 경우와 상이하다.

\section{3. 표본구성과 연구방법}

\section{1 표본 구성}

본 연구의 표본은 2004년부터 2016년까지 13년 동안 공시된 유상증자 중에서 기존 주주에게 신주에 대한 권리를 우선적으로 부여하는 방식인 주주배정방식(보다 자세하게, 주주배정 후 실권주 일반공모 방식, 주주배정방식, 주주우선공모방식)만을 대상으로 한다.9) 그리고 다음과 같은 추가적인 조건을 부여한다.

(1) 금융업종에 속하지 않으며 보통주만을 발행한 경우로 제한한다.

(2) 공시일, 권리락일, 신주상장일 전후 초과수익률을 계산할 수 있는 수익률 자료가 존재한다.

(3) 공시 전년도말 기준으로 기본적인 통제변수를 구할 수 있다.

(4) 실제로 유상증자가 실시되었다.

(5) 권리락을 배당락과 동시에 실시하는 권배락의 경우는 제외한다.

(6) 유상증자가 무상증자와 동시에 실시되지 않으며, 유상증자 공시후 상장일까지 무상증자, 주식분할, 주식병합, 감자 등을 실시하지 않는다.

이상의 조건을 부여한 결과 총 618 건의 주주배정방식이 확보되었다.10) 이 중에서 코스피기업이 실시한 유상증자는 $21 \%$ 인 132 건이고 코스닥기업이 실시한 유상증자는 $79 \%$ 인 486건이다. 그리고 주주배정 후 실권주 일반공모 방식에 의한 경우가 $66 \%$ 인 407건이고, 나머지 $34 \%$ 인 211건은 주주배정방식 또는 주주우선공모방식에 의한 경우이다. 연도별 현황은 다음과 같다. 글로벌 금융위기가 발생한 후 2010 2012년 기간에 주주배정방식 유상증자 건수가 크게 감소했음을 확인할 수 있다.

8) Hwang and Shin(2007)은 분할일 이후 6일 동안 누적초과수익률이 $-10.88 \%$ 라고 보고한다(<표 9>로부터 저자가 계산함).

9) 주주우선공모방식은 2006년 이후 거의 이용되지 않고 있다.

10) 분석에 필요한 주가와 수익률 자료는 FnGuide에서 입수하였으며 재무제표 자료는 상장사협의회 데이터베이스인 TS2000에서 입수하였다. 
〈표 1〉 주주배정방식 유상증자의 연도별 현황

\begin{tabular}{cccc}
\hline 연도 & 표본수 & 연도 & 표본수 \\
\hline 2004 & 43 & 2011 & 18 \\
2005 & 91 & 2012 & 12 \\
2006 & 65 & 2013 & 38 \\
2007 & 73 & 2014 & 37 \\
2008 & 64 & 2015 & 44 \\
2009 & 45 & 2016 & 59 \\
2010 & 29 & 합계 & 618 \\
\hline
\end{tabular}

$<$ 표 2>는 표본에 대한 기초 통계량이다. 패널 $\mathrm{A}$ 는 유상증자기업의 총자산, 부채비율(LEV), 자기자본순이익률(ROE), 영업현금흐름 $(\mathrm{OCF})$ 의 평균, 중앙값과 5퍼센타일 및 95퍼센타일을 보여준다. $\mathrm{ROE}$ 와 $\mathrm{OCF}$ 의 평균(중앙값)이 각각 $-28.4 \%(-2.6 \%)$ 와 $-3.2 \%(-0.4 \%)$ 로 상당히 낮음을 알 수 있다. 또한 $\mathrm{ROE}$ 와 $\mathrm{OCF}$ 를 연도별 중앙값에 대해 조정한 median-adjusted ROE와 median-adjusted $\mathrm{OCF}$ 의 경우 0보다 높은 비율이 각각 $25 \%$ 와 $28 \%$ 일 정도로 경영성과의 악화 정도가 상당히 심각함을 알 수 있다.

\section{〈표 2〉기초 통계량}

총자산은 자산의 장부가치이고, $\mathrm{LEV}$ 는 총부채를 자기자본의 장부가치로 나눈 값이고, $\mathrm{ROE}$ 는 순이익을 자기자본의 장부가치로 나눈 값이고, OCF는 영업현금흐름을 총자산으로 나눈 값이다. median-adjusted $\mathrm{ROE}(\mathrm{OCF})$ 는 $\mathrm{ROE}(\mathrm{OCF})$ 에서 연도별 중앙값을 차감하여 구한다. 패널A에서 $\mathrm{LEV}, \mathrm{ROE}, \mathrm{OCF}$ 의 경우 상하위 각 $5 \%$ 에 대하여 winsorization을 실시한다.

패널 $\mathrm{A}$ : 유상증자기업 관련 변수

\begin{tabular}{lrrrrc}
\hline \multicolumn{1}{c}{ 구분 } & 평균 & 중앙값 & 5퍼센타일 & 95퍼센타일 & 비율>0 비율 \\
\hline 총자산(억원) & 3,845 & 602 & 117 & 9,422 & - \\
$\mathrm{LEV}$ & 1.80 & 1.32 & 0.10 & 6.19 & - \\
$\mathrm{ROE}$ & -0.284 & -0.026 & -2.058 & 0.278 & $47 \%$ \\
$\mathrm{OCF}$ & -0.032 & -0.004 & -0.343 & 0.144 & $46 \%$ \\
median-adjusted ROE & -0.352 & -0.090 & -2.127 & 0.186 & $25 \%$ \\
median-adjusted OCF & -0.075 & -0.049 & -0.384 & 0.100 & $28 \%$ \\
\hline
\end{tabular}

패널 $\mathrm{B}$ : 유상증자 관련 변수

\begin{tabular}{lrccc}
\hline \multicolumn{1}{c}{ 구분 } & 평균 & 중앙값 & 5퍼센타일 & 95퍼센타일 \\
\hline 조달금액(억원) & 299 & 139 & 36 & 1,049 \\
할인율(\%) & 26 & 30 & 15 & 35 \\
배정비율(\%) & 66 & 37 & 13 & 200 \\
\hline
\end{tabular}

패널 $\mathrm{B}$ 는 유상증자와 관련하여 조달금액, 할인율, 배정비율에 대한 기초 통계량을 보여준다. 평균 조달금액은 299 억 원이고 평균 할인율은 $26 \%$ 이다. 그리고 배정비율의 평균은 $66 \%$ 이고 중앙값은 $37 \%$ 이다. 배정비율 $66 \%$ 는 주식 1주를 보유한 주주가 신주 0.66 주를 배정받을 수 있음을 의미한다. 종합적으로, 기존의 자기자본 대비 유상증자 규모가 결코 작지 않음을 보여준다. 
Price Adjustments on Ex-Right Dates in Cases of Right Offerings

\section{2 방법론}

\subsection{1 초과수익률}

유상증자 공시가 이루어지는 경우 공시효과를 측정하기 위한 초과수익률 AR(abnormal return: AR)은 다음과 같은 시장조정수익률모형을 이용한다.

$$
A R_{j t}=r_{j t}-r_{m t}
$$

단, $A R_{j t}$ 는 $j$ 기업의 $t$ 일의 초과수익률, $r_{j t}$ 는 $j$ 기업의 $t$ 일의 수익률, 그리고 $r_{m t}$ 는 주가지수의 $t$ 일의 수익률이다. 시장수익률로 종합주가지수(KOSPI) 또는 코스닥지수를 이용한다. 그리고 유상증자 공시효과의 경우 다음과 같은 시장모형을 이용하여 결과가 동일한지 추가로 검증한다.

$$
A R_{j t}=r_{j t}-\left(\hat{\alpha_{j}}+\hat{\beta}_{j} r_{m t}\right)
$$

$\hat{\alpha}$ 와 $\hat{\beta}$ 는 공시일 21 일전부터 150 일전까지의 일별수익률에 적용하여 최소자승법을 통해 추정한다.

그리고 사건일을 전후한 $-k$ 일부터 $+k$ 일까지의 $j$ 기업의 누적초과수익률 CAR(cumulative abnormal return)은 다음과 같이 구하며 평균 $\mathrm{CAR}$ 이 0과 상이한가를 검증하기 위하여 t검증을 실시한다.

\subsection{2 거래량 분석}

$$
C A R(-k,+k)=\sum_{t=-k}^{k} A R_{j t}
$$

투자자의 거래가 정보거래인지를 판단하기 위한 지표로 비정상거래량, 거래불균형, 순매수 비율을 이용하기로 한다. 이는 Lim and Yoon(2017), Yoon(2019)에서 사용한 지표와 동일하며 여기서는 방법론을 그대로 인용하기로 한다.

비정상거래량(abnormal trading volume: ATV)은 비사건기간(유상증자 전 일정기간)의 단기 거래량을 기준으로 권리락일을 전후하여 초과거래량을 계산한다(Foster and Viswanathan, 1995; Chae, 2005). 초과거래량을 계산하기 위해 먼저 일별 거래량 TV을 다음과 같이 계산한다.

$$
T V_{i, j, t}=\log \left(\frac{V B_{i, j, t}+V S_{i, j, t}}{\# \text { shares }}+0.00000255\right)
$$

여기서 $V B_{i, j, t}$ 는 $i$ 기업의 투자자 유형 $j$ 의 $t$ 일의 매수거래량이고 $V S_{i, j, t}$ 는 동일한 방식으로 정의된 매도거래량이며, \#shares는 전년도 말 기준 발행주식수이다. 여기서 투자자 유형은 기관투자자, 개인투자자, 외국인투자자 등 세 가지이다. 그리고 $\mathrm{TV}$ 로부터 비사건기간(유상증자 공시일 기준으로 -200 일부터 -41 일까지)의 평균 $\overline{T V}_{i, j}$ 을 차감하여 비정상거래량을 계산한다.

$$
A T V_{i, j, t}=T V_{i, j, t}-\overline{T V_{i, j}}
$$


거래의 방향을 확인하기 위하여 거래불균형과 순매수비율을 이용한다. 거래불균형(trade imbalance: TI)은 다음과 같이 계산된다.

$$
T I_{i, j, t}=\frac{V B_{i, j, t}-V S_{i, j, t}}{V B_{i, j, t}+V S_{i, j, t}}
$$

그리고 비사건기간 TI의 평균과 표준편차를 이용하여 표준화된 거래불균형(standardized trade imbalance: STI)을 계산한다.

$$
S T I_{i, j, t}=\frac{T I_{i, j, t}-\overline{T I}_{i, j}}{\operatorname{std}\left(T I_{i, j}\right)}
$$

여기서 $\overline{T I_{i, j}}$ 와 $\operatorname{std}\left(T I_{i, j}\right)$ 는 각각 비사건기간 $\mathrm{TI}$ 의 평균과 표준편차이다.

그리고 순매수비율(net purchase ratio: NPR)은 다음과 같이 매수거래량과 매도거래량간의 차이를 발행주식수로 나눈 후 100 을 곱하여 계산한다.

$$
N P R_{i, j, t}=\frac{V B_{i, j, t}-V S_{i, j, t}}{\# \text { shares }} \times 100
$$

\section{3 주주배정 유상증자의 주요 일정}

주주배정 유상증자에 연관된 일정은 유상증자 공시일, 1 차 발행가격 공시일, 권리락일, 발행가격 확정일, 그리고 신주상장일이다. 우리 618개 표본의 경우 주요 일정간 평균 거래일(trading day) 수는 <그림 $1>$ 과 같다(괄호안의 숫자는 중앙값임). 공시일부터 신주상장일까지 소요되는 기간은 평균 54 거래일인데, 1 개월의 거래일이 평균 21 일이므로 대략 2.6 개월이다(중앙값은 50 거래일). 세분하면, 공시일부터 권리락일까지 18 거래일, 권리락일부터 최종발행가격 확정일

\section{〈그림 1〉 주요 일정간 거래일수}

그림은 공시일, 권리락일, 최종발행가격 확정일, 그리고 신주상장일간의 거래일수를 보여준다. 괄호안의 값은 중앙값이다.

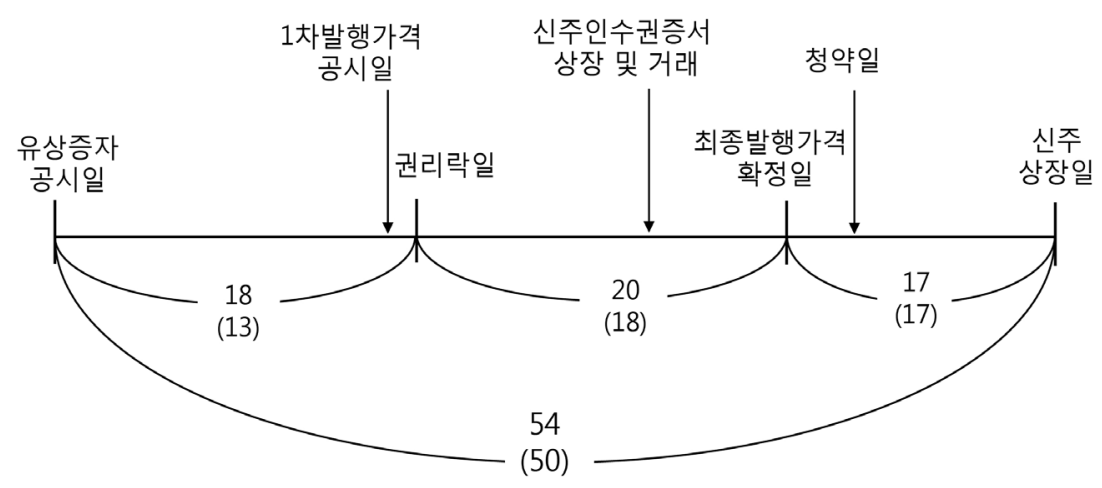


Price Adjustments on Ex-Right Dates in Cases of Right Offerings

까지 20거래일, 그리고 최종발행가격 확정일부터 신주상장일까지 17 거래일이 소요된다. 그리고 대략적으로 권리락일은 1 차 발행가격 공시일 이틀 후이며, 신주인수권증서가 상장되어 거래 된다면 이는 권리락일 이후이고 최종발행가격 확정일 이전이다(신주인수권증서는 거의 대부분의 경우 5 일 동안 거래되며, 신주인수권증서가 상장폐지되면 평균 5 거래일 이후에 최종발행가격이 확정됨).11) 또한 최종발행가격 확정 3거래일 이후가 청약일이다.

자본시장과 금융투자업에 관한 법률이 2009년 시행되면서 주주배정 증자방식의 주식발행가액 결정은 특정 기준 없이 발행사가 자율적으로 결정하도록 되어 있다(증권의 발행 및 공시 등에 관한 규정 제5-18조). 그러나 대부분의 주주배정 증자방식에서 과거 기준(구 유가증권발행 및 공시 등에 관한 규정 제57조)에 따라 유상증자가 진행된다.

제 57 조에 의하면 1 차 발행가액은 신주배정기준일 3 거래일전에 결정된다. 신주배정기준일 바로 전일이 권리락일이므로 결국 1 차 발행가격 결정 이틀 후가 권리락일이 된다. 본 연구는 1 차 발행가격이 공시된 상황에서 이루어지는 권리락일의 주가조정에 대해 분석하기로 한다.

\section{4. 실증 결과}

\section{1 유상증자의 공시효과}

주주배정방식 유상증자의 공시효과(announcement effect)는 <표 3>과 같다.12) Yoon et al.(2017), Yoon and $\operatorname{Lim}(2018)$, Yoon(2019)과 일관성있게, 유상증자 공시가 장후(after trading)에 이루어지면 익일(다음 날)을 공시일로 변경한다. 618건의 공시 중에서 장후에 공시되어 공시일이 익일로 변경된 건은 482건으로 78\%에 이른다. $78 \%$ 는 Yoon(2019)이 보고하는 91\%에 비하면 상당히 낮은데 이유는 Yoon et al.(2017)이 보고하듯이, 최근에 올수록 장후공시비율이 증가하기 때문이다(Yoon(2019)의 표본기간은 2011년부터 2016년까지임).

공시일(announcement date: $\mathrm{AD}$ )을 전후한 유의적인 주가반응은 -2 일부터 +1 일까지 4 일 동안 발생하며 가장 큰 주가반응은 공시일에 발생한다. 공시일의 초과수익률은 평균이 $-8.98 \%$ $(\mathrm{t}-\mathrm{value}=-32.01)$ 이고 중앙값은 $-10.87 \%$ 이다. 또한 공시일의 초과수익률이 0 보다 큰 비율은 단 $10 \%$ 에 지나지 않는다. 그리고 공시일을 전후한 3 일간 $(-1$ 일부터 +1 일까지 $)$ 의 누적초과 수익률은 $-12.74 \%$ 이고 $(\mathrm{t}-\mathrm{value}=-19.02)$ 0보다 큰 비율은 $18 \%$ 이다. $<$ 표 $3>$ 의 결과는 Yoon (2019)의 결과와 매우 유사하다. Yoon(2019)은 공시일의 초과수익률이 $-9.98 \%(\mathrm{t}-\mathrm{value}=$ -21.96)이고 3일간의 누적초과수익률이 $-12.61 \%(t-v a l u e=-19.6)$ 로 보고한다.

주주배정방식 유상증자의 공시효과는 일반공모방식 또는 제 3 자배정방식의 공시효과와 비교 된다. 주주배정방식과 일반공모방식은 모두 공시효과가 유의적인 음 $(-)$ 인데 주주배정방식 공시효과가 일반공모방식 공시효과보다 더 부정적이다. 예를 들어, Yoon(2016a)은 일반공모 777 건의 3 일 누적초과수익률은 $-4.15 \%$ 이라고 보고한다. 그리고 미국 제 3 자배정의 긍정적

11) 주주우선공모의 경우 신주인수권증서가 상장되어 거래되지 않는다.

12) 시장모형을 적용해도 결과는 거의 차이가 없으므로 결과 보고는 생략하기로 한다. 
한국증권학회지 제49권 3호 (2020)

공시효과와 유사하게, Lim et al.(2019)은 우리나라 제3자배정 1,796건의 3일 누적초과수익률은 $7.14 \%$ 라고 보고한다.

공시일을 전후하여 $12 \%$ 대의 주가하락은 우리나라의 기존 연구보다 그리고 외국의 연구보다 훨씬 큰 값으로(절대값이 크다는 의미임) 우리나라에서 주주배정방식 유상증자가 주주의 부에 미치는 영향이 매우 크다는 것을 알 수 있다.

\section{〈표 3〉 공시일 전후의 초과수익률}

이 표는 유상증자의 공시일 $(\mathrm{AD})$ 을 전후한 초과수익률을 분석한다. 장후에 공시되면 익일을 공시일로 변경한다. 여기서 초과수익률은 시장조정모형을 이용하여 추정한다. ${ }^{* * *},{ }^{* * *}$ 는 각각 $10 \%, 5 \%, 1 \%$ 수준에서 통계적으로 유의함을 의미한다. 중앙값에 대해서는 Wilcoxon signed rank test를 적용한다.

\begin{tabular}{ccccc}
\hline 공시일 기준 & 평균 & t-value & 중앙값 & 초과수익률>0 비율 \\
\hline-5 & 0.0025 & 1.35 & -0.0043 & $45 \%$ \\
-4 & -0.0019 & -1.05 & $-0.0064^{* * *}$ & $43 \%$ \\
-3 & 0.0003 & 0.17 & -0.0029 & $46 \%$ \\
-2 & -0.0044 & $-2.28^{* *}$ & $-0.0067^{* * * *}$ & $41 \%$ \\
-1 & -0.0129 & $-6.57^{* * *}$ & $-0.0122^{* * *}$ & $36 \%$ \\
$\mathrm{AD} 0$ & -0.0898 & $-32.01^{* * *}$ & $-0.1087^{* * *}$ & $10 \%$ \\
1 & -0.0215 & $-8.93^{* * *}$ & $-0.0141^{* * *}$ & $36 \%$ \\
2 & 0.0009 & 0.48 & -0.0008 & $49 \%$ \\
3 & -0.0019 & -1.15 & $-0.0037^{* * *}$ & $43 \%$ \\
4 & -0.0001 & -0.07 & $-0.0043^{*}$ & $45 \%$ \\
5 & 0.0013 & 0.72 & -0.0030 & $46 \%$ \\
\hline
\end{tabular}

\section{2 권리락일에서의 주가조정}

\subsection{1 효율적인 주가조정의 조건}

유상증자 권리락일 전일에 주식을 매입하고 거래일 포함하여 3 일째 되는 신주배정기준일 (신주를 우선 배정받을 주주를 확정하기 위하여 주주명부를 폐쇄하는 일)에 주주로 등록되면 신주를 받을 수 있는 권리인 신주인수권(preemptive right)이 부여된다. 그러나 권리락일에 주식을 매입하면 신주인수권이 소멸되는데 권리가 소멸된 후의 주가를 권리락가격이라고 한다. 따라서 권리락일에 주가는 신주인수권의 가치만큼 하락한다.

유상증자 전·후에 주주의 부가 변하지 않아야 하므로 권리락가격(ex-right price)과 권리부가격 (cum-right price) 사이에 다음 관계가 성립한다(배정비율을 증자비율이라고도 함).

권리부가격 + 신주발행가격 $\times$ 배정비율 $=$ 권리락가격 $\times(1+$ 배정비율 $)$

이 식으로부터 이론적인 권리락가격이 다음과 같이 유도된다.

$$
\text { 이론권리락가격 }=\frac{\text { 권리부가격 }+1 \text { 차발행가격 } \times \text { 배정비율 }}{1+\text { 배정비율 }}=\text { 기준가격 }
$$

권리락일에 최종발행가격이 확정되어 있지 않으므로 1 차 발행가격을 이용한다. 우리 표본의 
Price Adjustments on Ex-Right Dates in Cases of Right Offerings

경우 권리락일은 공시일로부터 18 거래일 이후에 위치하며 1 차 발행가격 공시일로부터 대부분의 경우 이틀 후에 위치한다.13)

유가증권시장본부와 코스닥시장본부는 권리락일의 주가조정이 효율적으로 이루어질 수 있도록 돕기 위하여 권리락일 하루 전 장후(after-trading) 시간에 권리락일이 내일이며 기준 가격이 얼마인지 공시한다.14) 거래소가 공시하는 기준가격은 식 (10)에 의해 계산된 이론권리락 가격이고 이 가격이 권리락일 시초가의 기준가격 역할을 하게 된다.15) 권리락일의 기준가격은 권리부가격, 1 차 발행가격, 배정비율을 반영한다. 발행가격이 확정되지 않아 차후에 변경될 가능성이 존재하지만 권리락일에 주가조정이 이루어질 때 1 차 발행가격이 공시된 상태이므로 이 가격을 이용하여 주가조정과 효율성을 검증해도 무리가 없다.16)

권리부가격(권리락일 전일의 종가)을 $C P_{-1}$ 로, 권리락일의 시가(opening price)와 종가(closing price)를 각각 $O P_{0}$ 와 $C P_{0}$ 로, 기준가격을 $R P$ 로 정의하자. 신주인수권의 가치(preemptive right value) $P R V$ 는 권리부가격에서 기준가격을 차감한 $C P_{-1}-R P$ 이다.

$$
\text { 신주인수권의 가치 } P R V=\text { 권리부가격 }- \text { 기준가격 }=C P_{-1}-R P
$$

<표 4>는 권리락일 전후 여러 지표의 기초 통계량을 보여준다. (4)는 신주인수권의 가치가 평균적으로 545 원이며 이는 (5)에 의해 권리부가격의 $11 \%$ 에 해당된다. 신주인수권의 가치는 식 (10)과 (11)에 의해 다음과 같이 정리된다. 이는 신주인수권의 가치가 권리부가격과 1 차 발행가격간의 차이 및 배정비율에 의해 결정됨을 보여준다.

$$
\text { 신주인수권의 가치 } P R V=\frac{\text { 배정비율 } \times(\text { 권리부가격 }-1 \text { 차발행가격 })}{1+\text { 배정비율 }}
$$

여기서 주의할 점은 $P R V$ 로 정의한 신주인수권의 가치가 주식 1 주를 매입할 수 있는 신주인수권의 가치가 아니라 주식 1 주에 부여된 신주인수권의 가치라는 점이다. 예를 들어, 배정비율이 $50 \%$ 이고 $P R V$ 가 1,000 원이면 보통주 1 주에 부여된 신주인수권의 가치가 1,000 원이고, 신주 1 주를 매입할 수 있는 신주인수권의 가치는 $\frac{1,000}{0.5}=2,000$ 원이다.

13) 앞에서 설명했듯이, 1 차 발행가격은 신주배정기준일 3 거래일 전에 결정된다. 그런데 권리락일이 신주배정기준일 바로 전일이므로 권리락일은 1 차 발행가격 결정일 2 거래일 후이다.

14) 거래소는 주식배당, 주주배정 방식 유상증자, 감자, 주식분할 등의 경우에 기준가격을 공시한다. 거래소가 기준가격을 공시하는 근거는 유가증권시장 업무규정 시행세칙 제 30 조이며 코스닥 기업의 경우에도 이 규정을 준용한다.

15) 이후 이론 권리락가격은 기준가격으로 대체하고 권리락가격은 권리락일의 실제 가격을 의미한다.

16) Yoon(2019)은 주주배정방식의 1차 발행가격과 최종발행가격을 비교한 결과 최종발행가격이 1 차 발행가격과 동일하거나 하락한 경우는 각각 $46 \%$ 와 $44 \%$ 이라고 보고한다. 이렿게 발행가격이 상승한 경우가 $10 \%$ 밖에 되지 않는 이유는 최종발행가격이 결정되는 방법이 최종발행가격이 상승하기가 어렵도록 정해져 있기 때문이라고 주장한다. 만약 식 (10)에서 발행가격이 상승하면 기준가격이 상승하게 되어 신주인수권의 가치는 하락한다. 물론 반대로 발행가격이 하락하면 기준가격이 하락하고 신주인수권의 가치는 상승한다. 최종가격결정 방법으로 인해 상승할 확률보다 하락할 확률이 크므로 신주인수권의 가치는 차후에 상승할 확률이 크다. 
권리락일에서의 수익률은 권리락가격과 기준가격으로부터 다음과 같이 계산된다.

$$
\text { 권리락일에서의 수익률 }=\frac{C P_{0}}{R P}-1
$$

만일 기준가격이 권리락일의 시가가 되어 거래가 시작되면 $O P_{0}=R P$ 이다. 그리고 권리락일 거래시간에 체계적으로 특별한 소식이 나오지 않는다고 가정하면 $O P_{0}=C P_{0}$ 이 되고 결국 식 (13)에 의해 계산된 권리락일에서의 수익률은 0 과 유의미하게 상이하지 않을 것이다.

만약 권리락일에 신주인수권의 가치만큼 정확히 주가(보다 정확하게 시가인 $O P_{0}$ )에 반영 된다면 $\frac{O P_{0}}{R P}=1$ 이어야 한다. 만약 분석 결과 $\frac{O P_{0}}{R P}=1$ 의 가설을 기각할 수 없으면 권리락일에서의 주가조정이 효율적으로 이루어짐을 의미한다. 만약 유의적으로 $\frac{O P_{0}}{R P}>1$ 이면 권리락일에 신주인수권의 가치가 과소 반영된 결과이고, 반대로 유의적으로 $\frac{O P_{0}}{R P}<1$ 이면 신주인수권의 가치가 과대 반영된 결과이다.

비율 $\frac{O P_{0}}{R P}$ 이 1 보다 큰 경우가 과소반영된 결과를 의미하여 독자가 혼동할 여지가 있으므로 역수인 $\frac{R P}{O P_{0}}$ 를 신주인수권가치 반영비율이라고 정의하자 $(<$ 표 $4>$ 의 (7)).

$$
\text { 신주인수권가치 반영비율 }=\frac{R P}{O P_{0}}
$$

신주인수권가치 반영비율이 1 보다 작으면(크면) 신주인수권의 가치가 권리락일의 주가에 과소(과대) 반영된 결과이고, 반영비율이 1 과 동일하면 권리락일에서의 주가조정이 효율적으로 이루어짐을 의미한다.

\subsection{2 실증결과: 주가조정의 비효율성}

<표 $4>$ 의 (1)에 의해 $C P_{0} / R P=1.0415$ 이므로 권리락일의 수익률이 $4.15 \%$ 이고 이는 매우 유의적이다(t-value=15.86). 그리고 (2)에 의해 $O P_{0} / R P=1.0424$ 이므로 권리락일의 시가가 기준가격보다 $4.24 \%$ 높게 출발하며(즉, 신주인수권가치 반영비율은 0.9613 임) 권리락일에서의 주가조정이 효율적으로 이루어지지 않음을 알 수 있다. 또한 (3)은 권리락일에서 시가 대비 종가의 비율이 1 과 차이가 없음을 보여준다. (1) (3)은 권리락일의 수익률이 $4.15 \%$ 로 매우 유의적인데 이는 시가가 기준가격보다 높게 출발하기 때문임을 보여준다.

<표 4>의 (7)에 의해 618건의 권리락일에서의 신주인수권가치 반영비율은 0.9613 또는 $96.13 \%$ 이다. 이는 반영되지 못한 신주인수권의 가치가 권리락시가의 $3.87 \%$ 임을 의미한다. 참고로 신주인수권가치 반영비율이 1 보다 작은 비율은 $83 \%$ 이다.

신주인수권가치 반영비율 $\left(R P / O P_{0}\right.$ 비율 $)$ 이 신주인수권가치의 크기에 의해 영향을 받는지 분석해 보자. 여기서 이용한 신주인수권가치의 크기는 절대적 크기가 아니라 권리부가격에 
Price Adjustments on Ex-Right Dates in Cases of Right Offerings

대한 상대적 크기이다. 상대적 크기로 $\frac{P R V}{C P_{-1}}$ 를 이용한다(<표 4>의 (5). 신주인수권의 가치가 크면 권리락일에 이에 상응하는 큰 폭의 주가조정이 발생해야 한다. 그런데 신주인수권의 가치가 클수록 상대적으로 주가조정이 충분히 이루어지지 않을 가능성이 크고 이로 인해 $R P / O P_{0}$ 이 1 보다 작을 개연성이 존재한다. 만일 신주인수권의 가치만큼 정확히 주가조정이 이루어지면 신주인수권가치 반영비율인 $R P / O P_{0}$ 비율은 1 이 된다.

〈표 4〉권리락일 전후 여러 지표

$C P_{-1}$ 는 권리부가격(권리락일 전일의 종가), $O P_{0}$ 와 $C P_{0}$ 는 각각 권리락일의 시가와 종가, $R P$ 는 기준가격이다. $P R V$ 는 신주인수권의 가치이다.

\begin{tabular}{lrrrr}
\hline \multicolumn{1}{c}{ 구분 } & 평균 & 중앙값 & 5퍼센타일 & 95퍼센타일 \\
\hline (1) 권리락종가/기준가격 $C P_{0} / R P$ & 1.0415 & 1.0280 & 0.9526 & 1.1493 \\
(2) 권리락시가/기준가격 $O P_{0} / R P$ & 1.0424 & 1.0330 & 0.9870 & 1.1462 \\
(3) 권리락종가/권리락시가 $C P_{0} / O P_{0}$ & 0.9994 & 0.9994 & 0.9242 & 1.0825 \\
(4) 신주인수권의 가치 $P R V=C P_{-1}-R P$ & 545 & 250 & 20 & 1,900 \\
(5) 신주인수권가치/권리부종가 $P R V / C P_{-1}$ & 0.1100 & 0.0864 & 0.0184 & 0.2967 \\
(6) 권리락종가/권리부종가 $C P_{0} / C P_{-1}$ & 0.9237 & 0.9346 & 0.7720 & 1.0309 \\
(7) 기준가격/권리락시가 $R P / O P_{0}$ & 0.9613 & 0.9680 & 0.8724 & 1.0132 \\
\hline
\end{tabular}

<표 5>는 신주인수권가치의 상대적 크기인 $\frac{P R V}{C P_{-1}}$ 를 기준으로 4 개의 그룹으로 나누고(이를 각각 Q1(쿼타일1), Q2(쿼타일2), Q3(쿼타일3), Q4(쿼타일4)로 칭함) 각 그룹의 신주인수권가치 반영비율을 계산한 결과이다. 식 (13)에 의해 $P R V$ 가 배정비율에 의해 가장 많이 영향을 받는데 우리 표본에서 $P R V / C P_{-1}$ 와 배정비율간의 상관계수는 0.70 이다(즉, 배정비율이 클수록 신주 인수권가치가 상대적으로 큼). $P R V / C P_{-1}$ 이 $\mathrm{Q} 1$ 에서 $\mathrm{Q} 4$ 로 가면서 순서대로 증가하는 것처럼, 반영비율을 의미하는 $R P / O P_{0}$ 도 $0.9887,0.9732,0.9600,0.9231$ 로 완벽하게 순서대로 하락한다.

모든 쿼타일(quartile)에서 $R P / O P_{0}$ 이 1 과 동일하다는 가설은 $1 \%$ 수준에서 기각되며 $R P / O P_{0}$ 이 1 보다 작은 비율은 $64 \% \sim 97 \%$ 에 이른다. $\mathrm{Q} 1$ 의 경우 $R P / O P_{0}$ 비율의 평균은 0.9887 (t-value $=-4.66$ )이고 1 보다 작은 비율은 $64 \%$ 이다, 반면에 $\mathrm{Q} 4$ 의 경우 $R P / O P_{0}$ 비율의 평균은 0.9231(t-value $=-20.45)$ 이고 1 보다 작은 비율은 무려 $97 \%$ 에 이른다. 17$)$ 그룹간에 $R P / O P_{0}$ 의 평균이 동일하다는 가설은 $1 \%$ 신뢰수준에서 기각된다. 권리락일의 시가를 이용하지 않고 종가를 이용해 $R P / C P_{0}$ 을 계산하면 그룹별 평균은 각각 $0.9946,0.9797,0.9626,0.9184$ 로 계산되며 (권리락일의 수익률은 각각 $0.76 \%, 2.32 \%, 4.15 \%, 9.38 \%$ 임) 네 그룹의 평균이 동일하다는 가설은 $1 \%$ 신뢰수준에서 기각된다. 18 )

17) t검증은 $R P / O P_{0}$ 에서 1 을 차감한 후 이 값이 0 과 상이한지를 검증한다.

18) 개별적으로 권리락일에서의 수익률은 $R P / C P_{0}$ 의 역수에서 1 을 차감한 값이다(식 (13) 참조). 그러나 수익률의 평균이 $R P / C P_{0}$ 의 역수에서 1 을 차감한 값의 평균과 반드시 일치하지는 않는다. 
한국증권학회지 제49권 3호 (2020)

어떤 정보가 주가에 즉각적으로 반영되지 않고 지연(delay)되는 현상은 여러 연구(순이익, $\mathrm{IPO}$, 유상증자, 자사주매입 등의 공시효과)에서 발견된다. 예를 들어, Foster et al.(1984)은 기대외 순이익의 크기에 따라 10 개의 포트폴리오를 구성하고 공시효과를 분석한 결과, 포트 폴리오1을 공매도하고 포트폴리오10을 매입하는 전략으로 공시후 60 일 동안 $17 \%$ 의 누적비정상 수익률을 얻는다고 보고한다. 같은 논리로 권리락일에 주가가 신주인수권의 가치만큼 하락해야 하지만 어떤 이유로 비효율성이 발생하여 덜 하락한다면 권리락일 이후에 지연되어 추가로 하락할 수 있다. 권리락일 이후의 주가하락은 권리락일 익일부터 신주상장일까지의 누적초과 수익률 $\left(C A R_{\text {post }}\right)$ 로 측정하기로 한다(<그림 $1>$ 에 의하면 권리락일부터 신주상장일까지의 평균 거래일수는 37일임).

$C A R_{\text {post }}$ 의 평균은 $-5.64 \%$ 이고 이는 $1 \%$ 신뢰수준에서 유의적이다. 신주인수권의 가치가 클수록 권리락일에서 주가조정이 덜 이루어지고 이후 추가적으로 주가가 하락하는 지연현상이 발생한다면 우리는 $\mathrm{Q} 1$ 에서 $\mathrm{Q} 4$ 로 가면서 순서대로 $C A R_{\text {post }}$ 는 모두 음의 값을 가지며 절대값이 커질 것으로 예상된다. <표 5>의 마지막 열에 보고된 누적초과수익률은 $-8.97 \% \sim-3.48 \%$ 범위에 속하며 완전히 순서대로 감소하지는 않지만 대체로 신주인수권의 가치가 클수록 누적초과수익률이 감소하는 현상을 보인다.

만약 권리락일에 주가조정이 효율적으로 이루어지지 않고 또한 주가조정이 신주상장일까지 지연된다고 가정하면 권리락일의 초과수익률과 $C A R_{\text {post }}$ 의 합은 0과 유의적으로 차이나지 않을 것이다. 19$)$ 분석 결과, 합은 $-1.40 \%$ 이고 $\mathrm{t}$ 값은 전혀 유의적이지 않다.

\section{〈표 5〉 쿼타일별 신주인수권가치 반영비율}

$C P_{-1}$ 는 권리부가격(권리락일 전일의 종가)이고 $O P_{0}$ 는 권리락일의 시가이고, $R P$ 는 기준가격이다. $P R V$ 는 신주인수권의 가치이다. $R P / O P_{0}$ 비율은 신주인수권가치 반영비율이다. $C A R_{\text {post }}$ 는 권리락일 익일부터 신주상장일까지의 누적초과수익률이다. $R P / O P_{0}$ 비율이 1 과 상이한지를 검증한다. *, ${ }^{* *},{ }^{* * *}$ 는 각각 $10 \%$, $5 \%, 1 \%$ 수준에서 통계적으로 유의함을 의미한다.

\begin{tabular}{|c|c|c|c|c|c|c|}
\hline & \multirow{2}{*}{ 관찰치 } & \multirow{2}{*}{$\frac{P R V}{C P_{-1}}$} & \multicolumn{3}{|c|}{$R P / O P_{0}$} & \multirow{2}{*}{$C A R_{\text {post }}$} \\
\hline & & & 평균 & 중앙값 & $R P / O P_{0}<1$ 비율 & \\
\hline Q1 & 154 & 0.0296 & $0.9887^{* * *}$ & $0.9904^{* * *}$ & $64 \%$ & $-4.61 \%^{* *}$ \\
\hline Q2 & 155 & 0.0701 & $0.9732^{* * *}$ & $0.9735^{* * *}$ & $83 \%$ & $-3.48 \% *$ \\
\hline Q3 & 155 & 0.1065 & $0.9600^{* * *}$ & $0.9635^{* * *}$ & $89 \%$ & $-5.51 \%{ }^{* *}$ \\
\hline Q4 & 154 & 0.2340 & $0.9231^{* * *}$ & $0.9188^{* * *}$ & $97 \%$ & $-8.97 \%^{* * *}$ \\
\hline
\end{tabular}

다른 변수들도 $C A R_{\text {post }}$ 에 영향을 미칠 수 있으므로 $C A R_{\text {post }}$ 를 종속변수로 그리고 발행금액, 총자산, 배정비율, 할인율, $R P / O P_{0}$ 를 독립변수로 하여 회귀분석하였으며 그 결과는 <표 $6>$ 과

19) 초과수익률은 <표 $7>$ 에 제시되어 있는데 권리락일의 수익률 $4.15 \%$ 와 초과수익률 $4.24 \%$ 는 거의 차이가 없고 $C A R_{\text {post }}$ 와의 일관성을 유지하기 위하여 여기서는 초과수익률을 이용하기로 한다. 초과수익률 대신에 수익률을 이용해도 결과는 차이가 없다. 
Price Adjustments on Ex-Right Dates in Cases of Right Offerings

같다. $R P / O P_{0}$ 는 $1 \%$ 신뢰수준에서 양으로 유의적이다 (t-value=3.22). 권리락일에 신주인수권 가치 반영비율이 낮을수록 $C A R_{p o s t}$ 도 낮아야 하므로 $R P / O P_{0}$ 는 양의 값을 가져야 한다. 그리고 $R P / O P_{0}$ 대신에 권리락일에서의 초과수익률인 $\mathrm{AR} 0$ 을 이용하면 이 변수도 $1 \%$ 신뢰수준에서 음으로 유의적이다 $(\mathrm{t}-\mathrm{value}=-4.05)$. 이 경우 권리락일에서의 초과수익률이 높을수록 주가가 덜 하락한 것이고 이후에 더 많이 하락해야 하므로 $\mathrm{ARO}$ 은 당연히 음의 값을 가져야 한다.

종합하면, $R P / O P_{0}$ 가 1 보다 유의적으로 작게 계산되는데 이는 권리락일에 신주인수권의 가치보다 작은 주가조정이 이루어지는 시장의 비효율성(inefficiency)을 의미한다. 또한 $R P / C P_{0}$ 도 1 보다 유의적으로 작은데 이는 권리락일의 수익률이 0 보다 유의적으로 큼을 의미한다. 권리부 종가에 비하여 신주인수권의 가치가 클수록 과소조정의 정도가 더 심할 것이라는 가설을 검증하기 위해 4 개의 쿼타일을 구성하여 분석한 결과, 모든 쿼타일에서 유의적인 과소조정이 이루어지며 $\frac{P R V}{C P_{-1}}$ 이 클수록 $R P / O P_{0}$ 도 감소하는 유의적인 음(-)의 관계를 갖는다. $\frac{P R V}{C P_{-1}}$ 과 $R P / O P_{0}$ 간의 상관계수는 -0.50 이고 $\frac{P R V}{C P_{-1}}$ 과 $R P / C P_{0}$ 간의 상관계수는 -0.64 이다. 또한 <표 6>은 신주 인수권가치 반영비율이 낮을수록(권리락일에 주가가 덜 하락할수록) 이후에 더 많이 하락한다는 결과를 보여주는데 이는 주가조정의 지연현상(delayed phenomenon)으로 이해된다.

〈표 6〉회귀분석(종속변수: $C A R_{\text {post }}$ )

이 표는 권리락일 익일부터 신주상장일까지의 누적초과수익률인 $C A R_{\text {post }}$ 를 종속변수로 사용한 회귀분석 결과이다. 두 번째 회귀식에서는 $R P / O P_{0}$ 대신에 권리락일에서의 초과수익률 $\mathrm{AR0}$ 을 사용한다.

$$
C A R_{\text {post }}=\alpha+\beta_{1} \ln (\text { 총자산 })+\beta_{2} \ln (\text { 발행금액 })+\beta_{3} \text { 배정비율 }+\beta_{4} \text { 할인율 }+\beta_{5} \frac{R P}{O P_{0}}+\epsilon
$$

초과수익률은 시장조정모형을 이용하여 추정한다. ${ }^{*},{ }^{* *}$, ***는 각각 $10 \%, 5 \%, 1 \%$ 수준에서 통계적으로 유의함을 의미한다.

\begin{tabular}{|c|c|c|c|c|}
\hline & \multicolumn{2}{|c|}{ (1) } & \multicolumn{2}{|c|}{ (2) } \\
\hline & 계수 & $\mathrm{t}$-value & 계수 & t-value \\
\hline 절편 & -0.824 & $-3.04^{* * *}$ & 0.030 & 0.39 \\
\hline $\ln$ (총자산) & 0.037 & $3.45^{* * *}$ & 0.033 & $3.12^{* * *}$ \\
\hline $\ln$ (발행금액) & -0.051 & $-3.47^{* * *}$ & -0.047 & $-3.16^{* * *}$ \\
\hline 배정비율 & 0.043 & $4.34^{* * *}$ & 0.042 & $4.35^{* * *}$ \\
\hline 할인율 & -0.277 & $-1.70^{*}$ & -0.256 & -1.57 \\
\hline 신주인수권가치 반영비율 $\frac{R P}{O P_{0}}$ & 0.862 & $3.22^{* * *}$ & & \\
\hline 권리락일 초과수익률 AR0 & \multirow{2}{*}{\multicolumn{2}{|c|}{$5.7 \%$}} & -0.705 & $-4.05^{* * *}$ \\
\hline adjusted $R^{2}$ & & & \multirow{2}{*}{\multicolumn{2}{|c|}{$\begin{array}{l}6.6 \% \\
9.77^{* * *}\end{array}$}} \\
\hline $\mathrm{F}$-value & \multicolumn{2}{|c|}{$8.50^{* * * *}$} & & \\
\hline
\end{tabular}

권리락일에 주가조정이 충분히 이루어지지 않는 현상은 앵커링 편의(anchoring bias)로 설명이 가능하다. 앵커링 편의는 Tversky and Kahneman(1974)에 의해 처음 제안되었다. 이는 의사 결정시 앵커라고 불리는 특정 값(먼저 입수되거나 제시된 정보 또는 수치)에 의해 의식적 또는 
한국증권학회지 제49권 3호 (2020)

무의식적으로 영향을 받는 심리적 편의이다. Chang et al.(2019)은 앵커링 편의를 주식배당과 주식분할에 적용한 결과, 권리락일의 초과수익률이 앵커링 편의로 인해 발생된다고 설명한다. 따라서 이 논리를 권리락 주가조정에 적용하면, 권리부가격이 앵커(anchor)의 역할을 하므로 투자자가 앵커인 권리부가격과 타겟(target)인 기준가격의 가중평균으로 권리락가격을 결정함 으로 인해 권리락일에 주가조정이 작게 이루어지게 되고 이로부터 초과수익률이 발생하게 된다는 설명이다.

\section{3 권리락일에서의 초과수익률}

$<$ 표 7>의 패널 $\mathrm{A}$ 는 권리락일(ex-right date: $\mathrm{ED})$ 을 전후한 초과수익률을 보여준다. 앞에서 설명했듯이, 거래소는 권리락일 하루 전 장후(after-trading) 시간에 권리락일이 내일이며 기준가격이 얼마인지 공시한다. 권리락일에 새로운 정보가 공시되는 것이 아니므로 <표 $7>$ 의 결과는 공시효과가 아니고 예정된 주가조정으로 인해 발생하는 수익률이다.

가장 유의적인 주가상승은 권리락일에 발생한다. 권리락일에 초과수익률의 평균은 $4.24 \%$ 이고 $(\mathrm{t}-\mathrm{value}=16.38)$ 이고 중앙값은 $2.75 \%$ 이며 $\mathrm{AR}>0$ 인 비율은 $71 \%$ 이다.20) 또한 유의적인 주가 상승이 이후 3 일간 지속되는 데, 초과수익률은 각각 $0.64 \%, 0.37 \%, 0.48 \%$ 이며 t-value는 각각 $2.83,1.90,2.33$ 이다. 권리락일 포함 4 일간의 누적초과수익률 $\mathrm{CAR}(0,3)$ 은 평균이 $5.73 \%$ 이고 t-value는 11.12 이고 $\mathrm{CAR}(0,3)>0$ 의 비율은 $64 \%$ 이다. 권리락일에서의 유의적인 양의 초과 수익률은 일본과 이탈리아에서의 결과와 유사하다(Goyal et al., 1994; Bolognesi and Gallo, 2013).

패널 $\mathrm{B}$ 는 신주인수권가치의 상대적 크기인 $\frac{P R V}{C P_{-1}}$ 를 기준으로 4 개의 그룹으로 구분한 쿼타일에 대한 분석이다. $\frac{P R V}{C P_{-1}}$ 이 커짐에 따라 권리락일의 초과수익률이 $1.09 \%, 2.48 \%, 4.10 \%, 9.31 \%$ 로 순서대로 증가한다. 마찬가지로 $\mathrm{Q} 1$ 에서 $\mathrm{Q} 4$ 로 가면서 $\mathrm{CAR}(0,3)$ 이 $2.38 \%, 3.28 \%, 4.22 \%$, $13.08 \%$ 로 커진다. 쿼타일간 권리락일 기준 $\mathrm{CAR}(0,3)$ 이 동일하다는 가설은 $1 \%$ 신뢰수준에서 기각된다.

특히 신주인수권의 가치가 가장 큰 $\mathrm{Q} 4$ 에서의 초과수익률은 매우 크게 나타난다. 권리락일의 초과수익률이 9.31\%(t-value $=16.09)$ 이고, $\operatorname{CAR}(0,3)$ 은 $13.08 \%$ 이고 $(\mathrm{t}-$ value $=9.22), \operatorname{CAR}(0$, $3)>0$ 의 비율은 $78 \%$ 이다(참고로 $\mathrm{Q} 4$ 의 권리락일 수익률은 $9.38 \%$ 임), <그림 $2>$ 는 권리락일을 전후하여 쿼타일별로 누적초과수익률의 패턴을 보여준다. $\mathrm{Q} 1, \mathrm{Q} 2, \mathrm{Q} 3$ 과 비교하여 $\mathrm{Q} 4$ 의 경우 권리락일에서의 초과수익률이 유난히 큼을 쉽게 확인할 수 있다. 앞에서 언급했듯이, 배정비율이 크면 신주인수권의 가치가 상대적으로 크게 계산된다.

$<$ 표 8>의 패널 $\mathrm{A}$ 는 권리락일에서의 초과수익률 결정요인을 분석하기 위하여 초과수익률을 종속변수로 하여 회귀분석한 결과이다. 구체적으로 종속변수로 권리락일의 초과수익률 $\mathrm{ARO}$ 과

20) 권리락일에서의 초과수익률 $4.24 \%$ 가 권리락시가를 기준가격으로 나눈 비율 1.0424 와 비슷한데 이는 우연의 일치이다. 
Price Adjustments on Ex-Right Dates in Cases of Right Offerings

권리락일을 전후한 누적초과수익률 $\operatorname{CAR}(0,3)$ 을 사용하기로 한다. 권리락일의 초과수익률을 이용한 첫 번째 회귀분석에서 배정비율이 클수록, 할인율이 클수록, 그리고 신주인수권가치 반영비율이 낮을수록 권리락일에서의 초과수익률이 유의적으로 크게 나타났으며, Adjusted $\mathrm{R}^{2}$ 는 $35 \%$ 이다. 그리고 앞의 <표 $5>$ 및 <표 $7>$ 의 결과와 일관성있게 가장 유의한 변수는 신주인수권가치 반영비율인 $\frac{R P}{O P_{0}}$ 이며 $\mathrm{t}-\mathrm{value}$ 는 -14.69 이다. 두 번째 회귀분석도 할인율이 유의적이지 않다는 점을 제외하고는 첫 번째 회귀분석 결과와 유사하다.

패널 $\mathrm{B}$ 는 회귀식에 사용된 변수간의 상관계수를 보여준다. $\mathrm{AR0}$ 과 $\mathrm{CAR}(0,3)$ 간의 상관계수는 0.60 으로 가장 높다. 그리고 $\frac{R P}{O P_{0}}$ 는 초과수익률과 매우 유의적인 부(-)의 상관성을 보이는데, 즉 $\mathrm{AR} 0$ 과 -0.58 의 상관계수를 그리고 $\mathrm{CAR}(0,3)$ 과 -0.45 의 상관계수를 갖는다.

〈표 7〉 권리락일 전후의 초과수익률

이 표는 유상증자 권리락일 $(\mathrm{ED})$ 을 전후한 초과수익률(AR)을 분석한다. 여기서 초과수익률은 시장조정 모형을 이용하여 추정한다. ${ }^{*},{ }^{* *},{ }^{* *}$ 는 각각 $10 \%, 5 \%, 1 \%$ 수준에서 통계적으로 유의함을 의미한다. 중앙값에 대해서는 Wilcoxon signed rank test를 적용한다. 패널B에서 그룹은 $\frac{P R V}{C P_{-1}}$ 을 이용하여 4 개의 쿼타일로 구성된다( $\mathrm{Q} 1$ 이 $\frac{P R V}{C P_{-1}}$ 비율이 가장 낮은 그룹임).

패널 $\mathrm{A}$ : 권리락일 전후 초과수익률

\begin{tabular}{rrccc}
\hline 권리락일 기준 & 평균 & t-value & 중앙값 & AR>0 비율 \\
\hline-5 & 0.0011 & 0.61 & -0.0022 & $47 \%$ \\
-4 & 0.0002 & 0.12 & -0.0039 & $44 \%$ \\
-3 & 0.0028 & 1.41 & -0.0018 & $47 \%$ \\
-2 & 0.0043 & $2.08^{* *}$ & -0.0004 & $49 \%$ \\
-1 & -0.0045 & $-2.05^{* *}$ & $-0.0022^{* *}$ & $46 \%$ \\
$\mathrm{ED} 0$ & 0.0424 & $16.38^{* * *}$ & $0.0275^{* * *}$ & $71 \%$ \\
1 & 0.0064 & $2.83^{* * *}$ & -0.0023 & $47 \%$ \\
2 & 0.0037 & $1.90^{*}$ & -0.0028 & $46 \%$ \\
3 & 0.0048 & $2.33^{* *}$ & -0.0029 & $46 \%$ \\
4 & 0.0017 & 0.90 & $-0.0034^{*}$ & $44 \%$ \\
5 & 0.0027 & 1.39 & -0.0032 & $46 \%$ \\
\hline
\end{tabular}

패널 B: 쿼타일별 초과수익률

\begin{tabular}{rcccc}
\hline & $\mathrm{Q} 1(\mathrm{n}=154)$ & $\mathrm{Q} 2(\mathrm{n}=155)$ & $\mathrm{Q} 3(\mathrm{n}=155)$ & $\mathrm{Q} 4(\mathrm{n}=154)$ \\
\hline-3 & 0.0018 & -0.0011 & 0.0050 & 0.0055 \\
-2 & -0.0061 & 0.0047 & 0.0037 & $0.0151^{* * *}$ \\
-1 & $-0.0106^{* * *}$ & -0.0062 & -0.0060 & 0.0051 \\
$\mathrm{ED} 0$ & $0.0109^{* * *}$ & $0.0248^{* * *}$ & $0.0410^{* * *}$ & $0.0931^{* * *}$ \\
1 & 0.0041 & 0.0024 & -0.0008 & $0.0201^{* * *}$ \\
2 & $0.0058^{*}$ & 0.0030 & -0.0030 & $0.0089^{*}$ \\
3 & 0.0029 & 0.0026 & 0.0051 & $0.0086^{*}$ \\
$\operatorname{CAR}(0,3)$ & $0.0238^{* * *}$ & $0.0328^{* * *}$ & $0.0422^{* * *}$ & $0.1308^{* * *}$ \\
\hline
\end{tabular}


〈그림 2〉 권리락일 전후 쿼타일별 누적초과수익률

이 그림은 권리락일을 전후하여 쿼타일별로 누적초과수익률을 그린 그래프이다. 초과수익률은 시장조정 모형을 이용하여 추정한다. $\frac{P R V}{C P_{-1}}$ 을 이용하여 4 개의 쿼타일을 구성한다(Q1이 $\frac{P R V}{C P_{-1}}$ 비율이 가장 낮은 그룹임).

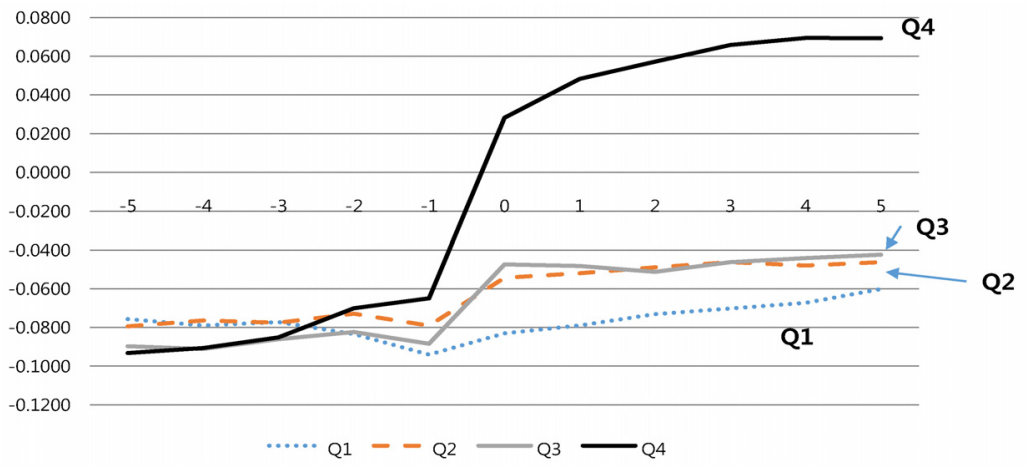

〈표 8〉 권리락일 초과수익률 결정요인에 대한 회귀분석 결과

이 표는 권리락일에서의 초과수익률 $\mathrm{AR} 0$ 과 누적초과수익률 $\mathrm{CAR}(0,3)$ 을 종속변수로 사용한 회귀분석 결과이다.

$$
A R(\text { or } C A R)=\alpha+\beta_{1} \ln (\text { 발행금액 })+\beta_{2} \text { 배정비율 }+\beta_{3} \text { 할인율 }+\beta_{4} \frac{R P}{O P_{0}}+\epsilon
$$

초과수익률은 시장조정모형을 이용하여 추정한다. ${ }^{*},{ }^{* *},{ }^{* * *}$ 는 각각 $10 \%, 5 \%, 1 \%$ 수준에서 통계적으로 유의함을 의미한다.

패널 $\mathrm{A}$ : 회귀분석 결과

\begin{tabular}{|c|c|c|c|c|c|c|}
\hline & \multicolumn{3}{|c|}{ (1) 종속변수: AR0 } & \multicolumn{2}{|c|}{ (2) 종속변수: $\operatorname{CAR}(0,3)$} \\
\hline & & 계수 & \multicolumn{2}{|c|}{ t-value } & 계수 & t-value \\
\hline 절편 & & 0.7694 & \multicolumn{2}{|c|}{$13.93^{* * *}$} & 0.9134 & $8.15^{* * *}$ \\
\hline $\ln$ (발행금액) & & 0.0007 & \multicolumn{2}{|c|}{0.34} & -0.0005 & 0.90 \\
\hline 배정비율 & & 0.0060 & \multicolumn{2}{|c|}{$2.94^{* * *}$} & 0.0427 & $10.38^{* * *}$ \\
\hline 할인율 & & 0.0847 & \multicolumn{2}{|c|}{$2.52^{* *}$} & 0.0036 & 0.05 \\
\hline 신주인수권가츠 & 반영비율 $\frac{R P}{O P_{0}}$ & -0.7876 & \multicolumn{2}{|c|}{$-14.69^{* * *}$} & -0.9179 & $-8.43^{* * *}$ \\
\hline \multirow{2}{*}{\multicolumn{2}{|c|}{$\begin{array}{l}\text { adjusted } \mathrm{R}^{2} \\
\mathrm{~F} \text {-value }\end{array}$}} & \multirow{2}{*}{\multicolumn{3}{|c|}{$\begin{array}{c}0.35 \\
82.70^{* * *}\end{array}$}} & \multirow{2}{*}{\multicolumn{2}{|c|}{$\begin{array}{c}0.32 \\
73.48^{* * *}\end{array}$}} \\
\hline & & & & & & \\
\hline \multicolumn{7}{|c|}{ 패널 $\mathrm{B}$ : 상관계수 분석 } \\
\hline \multicolumn{2}{|r|}{$\mathrm{AR0}$} & $\operatorname{CAR}(0,3)$ & $\ln ($ 발행금액) & 배정비율 & 할인율 & $\frac{R P}{O P_{0}}$ \\
\hline AR0 & - & & & & & \\
\hline $\operatorname{CAR}(0,3)$ & $0.60^{* * *}$ & - & & & & \\
\hline $\ln ($ 발행금액 $)$ & -0.03 & -0.02 & - & & & \\
\hline 배정비율 & $0.30^{* * *}$ & $0.49^{* * *}$ & -0.01 & - & & \\
\hline 할인율 & $0.17^{* * *}$ & 0.05 & $-0.11^{* * *}$ & -0.01 & - & \\
\hline$\frac{R P}{O P_{0}}$ & $-0.58^{* * *}$ & $-0.45^{* * *}$ & 0.06 & $-0.38^{* * *}$ & $-0.16^{* * *}$ & - \\
\hline
\end{tabular}


Price Adjustments on Ex-Right Dates in Cases of Right Offerings

권리락일에 유의적인 양의 초과수익률이 관찰된다는 사실은 권리부가격에 매입하고 권리락 가격에 매도하는 것이 투자기회를 제공한다는 것을 의미한다. 권리부가격(종가)에 매입하고 권리락가격(종가)에 매도하면 현금흐름은 $-C P_{-1}+C P_{0}$ 이고 투자자는 신주인수권을 갖게 된다. 그런데 신주인수권의 가치가 $C P_{-1}-R P$ 이므로 결국 투자자 포지션의 가치는 다음과 같다.

$$
-C P_{-1}+C P_{0}+C P_{-1}-R P=C P_{0}-R P
$$

$\frac{C P_{0}}{R P}-1$ 이 권리락일의 수익률인데 권리락일에 유의적인 양의 수익률이 발생한다는 사실은 $C P_{0}>R P$ 이며 그 차이인 $C P_{0}-R P$ 도 0 보다 유의적으로 크다는 것을 의미한다. <표 $4>$ 에서 권리락일의 수익률은 $4.15 \%$ 이고 <표 $7>$ 에서 초과수익률은 $4.24 \%$ 이다.

\section{4 신주인수권증서의 상장제도가 미치는 영향}

신주인수권증서(preemptive right certificate)의 상장은 2002년 신성이엔지에 의해 최초로 시행된 이후 일부 기업들에 의해 시행되었으며 2013년 자본시장법의 개정으로 주주배정방식 유상증자의 경우 의무화되었다. 신주인수권증서가 상장되어 거래됨에 따라 이 제도가 미치는 효과는 다음과 같다(Yoon, 2019). 첫째, 유상증자 참여를 원하지 않는 주주가 신주인수권을 공정한 가격으로 개인적으로 매도하는 것이 불가능하여 소액주주의 이익이 침해되었으나 상장제도 도입이후 신주인수권증서를 매도함으로써 공정한 가격으로 신주인수권을 매도할 수 있게 된다. 둘째, 권리락일 전에 주식을 공매도하는 경우 신주인수권을 반환할 수 없어 권리락일 전에 공매도 포지션을 마감하여야 하지만 상장제도 도입이후 신주인수권을 원소유자에게 반환할 수 있어 권리락일 이후까지 공매도 포지션을 연장할 수 있도록 함으로써 시장의 효율성에 기여한다. 셋째, 투자자는 신주인수권증서의 거래를 통한 새로운 투자기회를 추가로 갖게 된다. 넷째, 신주인수권증서와 주가간에 균형관계가 성립하며 이 관계가 성립되지 않으면 차익거래기회가 발생하며(신주인수권증서는 사실상 콜옵션이므로 콜옵션 가격의 상한선과 하한선 범위를 벗어나면 차익거래가 발생함) 이는 시장의 효율성을 향상시킬 수 있다. 다섯째, 유상증자에 참여할 수 없는 비주주에게 주식을 매입할 수 있는 새로운 기회를 제공한다.

신주인수권증서의 상장 및 거래가 이처럼 시장에서 다양한 긍정적인 역할을 수행하여 시장의 효율성을 향상시킨다면 권리락일에서의 주가조정에 반영되는 비효율성을 감소 또는 완화시킬 수 있을 것이므로 이를 검증하기 위하여 회귀분석을 시도하며 결과는 <표 $9>$ 와 같다.

회귀식의 종속변수는 신주인수권가치 반영비율 $\frac{R P}{O P}$ 이고 $L I S T I N G$ 은 신주인수권증서가 상장되는 유상증자의 경우 1 의 값을 갖는 더미변수이다. 첫 번째 회귀식의 경우 LISTING변수만을 이용하므로 두 그룹간 차이에 대한 단일변량분석이다. 신주인수권증서가 상장되면 이는 신주인수권가치 반영비율을 $1.63 \%$ 포인트 상승시키며 이는 $1 \%$ 신뢰수준에서 유의적이다. 반영비율이 상승한다는 것은 비효율성의 정도가 완화됨을 의미한다.

두 번째 회귀식은 신주발행기업의 총자산 크기, 증자규모, 할인율, 배정비율, LISTING을 이용한다. 총자산이 클수록 정보비대칭이 감소하므로 총자산이 클수록 주가조정이 효율적으로 이루어질 것으로 예상되어 $\ln$ (총자산)은 양의 부호가 예상된다. 반면에 투자금액, 할인율, 
한국증권학회지 제49권 3호 (2020)

배정비율의 경우 클수록 주가조정이 덜 이루어질 가능성이 크므로 모두 음의 부호가 예상된다. 예상과 같이, $\ln$ (총자산)은 신주인수권가치 반영비율과 유의적인 양의 관계를 갖는 반면, $\ln$ (투자금액), 할인율, 배정비율은 모두 반영비율과 유의적인 음의 관계를 갖는다. 즉, 총자산이 클수록 반영비율은 상승하지만, 발행금액, 할인율, 배정비율이 클수록 반영비율은 감소한다 (반영비율이 감소함은 신주인수권가치가 더 적게 반영됨을 의미함). 그리고 $L I S T I N G$ 의 계수는 0.0071 이고 5\% 신뢰수준에서 양으로 유의적인데 이는 신주인수권증서 상장으로 인해 신주 인수권가치 반영비율이 $0.71 \%$ 포인트 상승함을 의미한다. 결론적으로, 신주인수권증서가 상장되면 권리락일에서의 주가조정이 상장되지 않은 경우와 비교하여 상대적으로 더 효율적으로 이루어진다.

\section{〈표 9〉 신주인수권증서 상장의 효과}

이 표는 신주인수권증서의 상장이 신주인수권가치 반영비율인 $R P / O P_{0}$ 에 미치는 영향을 분석하기 위한 회귀분석 결과이다.

$$
\frac{R P}{O P_{0}}=\alpha+\beta_{1} \ln (\text { 총자산 })+\beta_{2} \ln (\text { 발행금액 })+\beta_{3} \text { 배정비율 }+\beta_{4} \text { 할인율 }+\beta_{5} \operatorname{LISTING+\epsilon }
$$

종속변수는 $R P / O P_{0}$ 이다. $L I S T I N G$ 은 신주인수권증서가 상장되는 경우 1 의 값을 갖는 더미변수이다. *, **, ${ }^{* * *}$ 는 각각 $10 \%, 5 \%, 1 \%$ 수준에서 통계적으로 유의함을 의미한다.

\begin{tabular}{|c|c|c|c|c|c|}
\hline & \multirow{2}{*}{ 예상 부호 } & \multicolumn{2}{|c|}{ (1) } & \multicolumn{2}{|c|}{ (2) } \\
\hline & & 계수 & t-value & 계수 & t-value \\
\hline 절편 & & 0.9561 & $462.41^{* * *}$ & 0.9745 & $83.62^{* * *}$ \\
\hline $\ln$ (총자산) & + & & & 0.0087 & $5.50^{* * *}$ \\
\hline $\ln$ (발행금액) & - & & & -0.0079 & $-3.55^{* * *}$ \\
\hline 배정비율 & - & & & -0.0121 & $-8.50^{* * *}$ \\
\hline 할인율 & - & & & -0.0967 & $-3.98^{* * *}$ \\
\hline LISTING & + & 0.0163 & $4.45^{* * *}$ & 0.0071 & $2.00^{* *}$ \\
\hline adjusted $R^{2}$ & & \multicolumn{2}{|c|}{0.03} & \multicolumn{2}{|c|}{0.22} \\
\hline $\mathrm{F}$-value & & \multicolumn{2}{|c|}{$19.79^{* * *}$} & \multicolumn{2}{|c|}{$35.84^{* * *}$} \\
\hline
\end{tabular}

\section{5 권리락일을 전후한 거래량 분석}

앞에서 권리락일에서의 주가조정을 분석한 결과는 신주인수권의 가치가 주가에 과소반영되고 있음을 보여준다. 이번에는 권리락일을 전후하여 기관투자자, 개인투자자, 외국인투자자 중 어떤 유형의 투자자가 권리락일 전후하여 집중적으로 거래하는지 투자자별 거래행태를 분석해 보자. 사용하는 지표는 Lim and Yoon(2017), Yoon(2019)과 정확히 동일하며 결과는 <표 $10>$ 과 같다.

먼저 권리락일의 비정상거래량을 보면(패널 A) 기관투자자, 개인투자자, 외국인투자자가 모두 비정상적으로 많은 거래를 하고 있음을 알 수 있다. 그리고 패널 $\mathrm{B}$ 와 패널 $\mathrm{C}$ 의 분석은 일관성있게 권리락일에 개인투자자는 매수우위를 보이고 외국인투자자는 매도우위를 보인다. 반면에 기관투자자는 권리락일을 전후하여 거래불균형과 순매수비율이 전혀 유의적이지 않다. 
Price Adjustments on Ex-Right Dates in Cases of Right Offerings

권리락일 전후로 분석을 넓히면 개인투자자는 '권리부매도 권리락매수’의 패턴을 보이고 외국인 투자자는 '권리부매입 권리락매도'의 패턴을 보인다.

\section{〈표 10〉권리락일 전후의 거래지표 분석}

이 표는 권리락일 $(\mathrm{ED})$ 을 전후한 기관투자자, 개인투자자, 외국인투자자의 주식에 대한 비정상거래량과 거래불균형 및 순매수비율의 통계량이다. 비사건기간은 유상증자 공시일 기준 -200 일부터 -41 일까지이다. ${ }^{*},{ }^{* *},{ }^{* * *}$ 는 각각 $10 \%, 5 \%, 1 \%$ 수준에서 통계적으로 유의함을 의미한다.

패널 $\mathrm{A}$ : 비정상거래량(ATV)

\begin{tabular}{rccc}
\hline 권리락일 기준 & 기관투자자 & 개인투자자 & 외국인투자자 \\
\hline-2 & 0.0741 & $0.6076^{* * * *}$ & $0.5323^{* * * *}$ \\
-1 & $0.3605^{* * *}$ & $0.9689^{* * *}$ & $0.7751^{* * * *}$ \\
$\mathrm{ED} 0$ & $0.3957^{* * *}$ & $0.6964^{* * *}$ & $0.7322^{* * *}$ \\
1 & 0.2092 & $0.2385^{* * *}$ & $0.5483^{* * * *}$ \\
2 & 0.1332 & $0.1834^{* *}$ & $0.4782^{* * *}$ \\
\hline
\end{tabular}

패널 $\mathrm{B}$ : 일별 거래불균형(STI)

\begin{tabular}{rccc}
\hline 권리락일 기준 & 기관투자자 & 개인투자자 & 외국인투자자 \\
\hline-2 & 0.1425 & $-0.1165^{*}$ & 0.0520 \\
-1 & $0.2479^{* *}$ & $-0.1704^{* * *}$ & $0.2361^{* * * *}$ \\
$\mathrm{ED} 0$ & -0.0279 & $0.4898^{* * *}$ & $-0.3543^{* * *}$ \\
1 & $-0.1777^{*}$ & -0.1247 & $0.1560^{* *}$ \\
2 & 0.1195 & $0.3424^{* *}$ & $-0.2938^{* * *}$ \\
\hline
\end{tabular}

패널 C: 일별 순매수비율(NPR)

\begin{tabular}{rccc}
\hline 권리락일 기준 & 기관투자자 & 개인투자자 & 외국인투자자 \\
\hline-2 & 0.0162 & $-0.0389^{* * *}$ & $0.0179^{* *}$ \\
-1 & -0.0150 & -0.0193 & $0.0336^{* * *}$ \\
$\mathrm{ED} 0$ & -0.0002 & $0.0484^{* * *}$ & $-0.0428^{* * *}$ \\
1 & -0.0006 & -0.0010 & 0.0070 \\
2 & 0.0000 & $0.0344^{* * *}$ & $-0.0330^{* * *}$ \\
\hline
\end{tabular}

\section{6 비효율적 주가조정으로 인한 투자기회}

권리락일에서의 초과수익률 $4.24 \%$ 는 투자자가 실제로 얻을 수 있는 수익률인가? 권리락일의 수익률은 기준가격을 이용하며 주가조정을 반영하는 수익률이므로, 권리부가격에 매입하고 권리락가격에 매도하여 $4.24 \%$ 의 초과수익률을 실제로 실현할 수 있는 것은 아니다.21)

그렇다면 권리락일에 주가조정이 비효율적으로 이루어진다면 투자자는 구체적으로 어떻게 이익을 실현할 수 있는가? 먼저 신주인수권이 상장되지 않는다고 가정하자. 투자자는 권리부 가격에 매입하고 권리락가격에 매도하여 신주인수권을 보유하며, 유상증자에 참여하고(즉,

21) 만약 권리락일 이후 주가와 발행가격이 변하지 않는다면 투자자는 대략적으로 $4.24 \%$ 의 초과수익률을 실현할 수 있다. 
한국증권학회지 제49권 3호 (2020)

최종발행가격을 납입하여 신주를 배정받고) 신주를 신주상장일 이틀 전에 매도할 수 있다. 매도 시점을 신주상장일 이틀 전으로 선택한 이유는 상장 이틀 전이 신주를 매도할 수 있는 가장 빠른 시점이기 때문이다. 이는 신주를 청약한 투자자가 이틀 후인 상장일까지 결제가 가능하기 때문이다(이를 권리공매도라고 함). 한편, Yoon(2016a)은 일반공모 방식 유상증자의 경우 상장일 이틀 전에 $3.88 \%$ 하락한다고 보고한다. <표 $4>$ 의 (3)에 의해 권리락시가에 매도하든 권리락종가에 매도하든 차이가 없으므로 거래를 시행할 때 권리락종가를 이용하기로 한다.

첫 번째 거래 전략의 수익률 $r e t 1$ 은 다음과 같이 계산된다.

$$
r e t 1=\frac{\text { 권리락종가 }+ \text { 신주상장일 이틀전 종가 } \times \text { 배정비율 }}{\text { 권리부종가 }+ \text { 최종발행가격 } \times \text { 배정비율 }}
$$

<표 4>의 (6)은 투자자의 매도가격이 매입가격의 $92 \%$ 임을 보여준다. 즉, 주식의 매매에서 $8 \%$ 손해를 보지만 대략 $30 \%$ 할인된 가격으로 신주를 매입하게 되므로(<표 $2>$ 에서 할인율의 평균은 $26 \%$ 이고 중앙값은 $30 \%$ 임) 투자자는 이 거래를 통해 이익을 얻을 개연성이 충분히 존재한다.22)

정부는 2013년 자본시장과 금융투자업에 관한 법률을 개정하여 신주인수권의 상장을 의무화 하였으며 최소 5 거래일동안 거래되도록 요구하였다. 만약 신주인수권이 상장되어 신주인수권 증서(preemptive right certificate)로 거래되면 투자자는 유상증자에 참여하지 않고 신주인수권 증서 상장 첫날에 신주인수권증서를 매도할 수 있으며 이 경우 수익률 ret 2 은 다음과 같이 계산된다.

$$
\operatorname{ret} 2=\frac{\text { 권리락종가 }+ \text { 신주인수권증서가격 } \times \text { 배정비율 }}{\text { 권리부종가 }}-1
$$

ret1과 ret2에 대한 분석 결과가 <표 $11>$ 에 보고되어 있는데 ret1의 경우 평균은 $2.59 \%$ 이고 이는 $1 \%$ 수준에서 유의적이다 $(\mathrm{t}-\mathrm{value}=4.24)$. 이는 51 일 기준이므로 이를 연 기준으로 전환하면 $2.59 \% \times \frac{365}{51}=18.54 \%$ 이다. 그러나 신주인수권증서를 직접 매도할 수 있는 경우의 수익률인 ret2의 성과는 전혀 유의적이지 않다. ret2가 계산되려면 신주인수권이 상장되어 거래되어야 하며 이 경우 표본수는 197 개로 감소한다. ${ }^{23)} \mathrm{ret} 2$ 의 평균은 $0.59 \%(\mathrm{t}-\mathrm{value}=0.86)$ 이고 중앙값은 $-0.80 \%$ 이다.24) 신주인수권증서를 직접 매도하는 경우의 수익률이 낮게 나온 현상은 Yoon(2019)의 결과와 일관성을 갖는다. Yoon(2019)은 신주인수권증서의 가격자료를 분석한 결과 신주인수권

22) 권리락일 이후에도 초과수익률이 +3 일까지 유의적이므로 투자자는 권리락일에 매도하는 것보다 +3 일에 매도하는 것이 더 유리하다.

23) 신주인수권증서의 거래가격 자료는 한국거래소에서 구입하였다.

24) 신주인수권증서 상장일이 신주상장일보다 앞서므로 투자자는 신주인수권증서 상장일에 ret2가 0보다 크면 신주인수권증서를 매도하고 ret2가 0보다 작으면 신주인수권증서를 매도하지 않고 유상증자에 참여하여 ret1을 실현하는 상황의존적 전략을 구사할 수 있다. 이 경우 수익률의 평균은 $1.95 \%$ 이고 $(\mathrm{t}-\mathrm{value}=2.98)$ 이고 중앙값은 $0.62 \%$ 이며 수익률이 0 보다 큰 비율은 $57 \%$ 이다. 
Price Adjustments on Ex-Right Dates in Cases of Right Offerings

증서가 시장에서 과소평가되어 거래된다고 보고한다. 따라서 과소평가된 신주인수권증서를 매도하는 전략이 유의적인 수익률을 실현하지 못함은 너무나 당연한 결과이다.

〈표 11〉 권리락일을 전후한 투자전략의 수익률

ret1과 ret2는 각각 다음과 같이 계산한다.

$$
\begin{gathered}
r e t 1=\frac{\text { 권리락종가 }+ \text { 신주상장일 이틀전 종가 } \times \text { 배정비율 }}{\text { 권리부종가 }+ \text { 최종발행가격 } \times \text { 배정비율 }}-1 \\
r e t 2=\frac{\text { 권리락종가 }+ \text { 신주인수권증서가격 } \times \text { 배정비율 }}{\text { 권리부종가 }}-1
\end{gathered}
$$

여기서 51 일은 권리락일부터 신주상장일 이틀 전까지의 달력일수이고, 22 일은 권리락일부터 신주인수권증서 상장일까지의 달력일수이다.

\begin{tabular}{lrr}
\hline & \multicolumn{1}{c}{ ret1 } & \multicolumn{1}{c}{ ret2 } \\
\hline 관찰치 & $\mathrm{n}=618$ & $\mathrm{n}=197$ \\
투자기간(달력일) & 51 일 & 22 일 \\
평균( $\mathrm{t}-$ value & $0.0259(\mathrm{t}=4.24)$ & $0.0059(\mathrm{t}=0.86)$ \\
중앙값 & 0.0052 & -0.0080 \\
최대값 & 2.6346 & 0.9121 \\
최소값 & -0.3167 & -0.3026 \\
\hline
\end{tabular}

이번에는 앞에서 했던 것처럼 4개의 쿼타일로 나누어 거래전략 수익률인 ret1을 분석해 보자. $<$ 표 $12>$ 패널 $\mathrm{A}$ 의 첫 번째 줄에 제시된 $\mathrm{Q} 1$ 에서 $\mathrm{Q} 4$ 의 $R P / O P_{0}$ 의 비율은 <표 $5>$ 에 제시된 값이다. 이 비율이 하락한다는 것은 상대적으로 권리락일에서의 주가조정에서 신주인수권가치가 반영되는 비율이 작음을 의미한다. 즉, 권리락일 시가가 기준가격까지 하락하지 못하고 높게 형성되므로 주가조정이 적게 이루어지는 것이다. 예를 들어, Q4의 0.9231 은 기준가격이 권리락일 시가의 92.31\%임을 의미한다. 쿼타일별 ret1의 평균과 중앙값은 두 번째와 세 번째 줄에 제시되어 있다. $\mathrm{Q} 1$ 에서 $\mathrm{Q} 4$ 로 가면서 순서대로 ret1이 $0.61 \%, 1.80 \%, 2.21 \%, 5.77 \%$ 로 증가하며 $\mathrm{Q} 1$ 을 제외하고 모두 $1 \%$ 신뢰수준에서 유의적이다. Q4의 $5.77 \%$ 는 51 일에 대한 수익률이므로 $(<$ 표 $11>$ 참조) 이를 1 년 기준으로 전환하면 $5.77 \% \times \frac{365}{51}=41.30 \%$ 이다. ${ }^{25)}$

본 논문은 권리락일에서의 주가조정이 효율적으로 이루어지지 않고 있음을 보고한다. 이런 비효율성은 정보비대칭이 심한 소기업의 경우 더 심할 것으로 판단된다. 패널 $\mathrm{B}$ 는 쿼타일별로 평균 총자산 규모, 조달금액, 할인율, 배정비율(증자비율)을 보여주는데, $\mathrm{Q} 1$ 이 대기업 중심으로 조달금액이 가장 크고 할인율과 배정비율이 가장 작다. 반면에 $\mathrm{Q} 4$ 는 소기업 중심으로 조달금액이 가장 작으나 특히 배정비율이 가장 크다. 결론적으로, 대기업을 제외한 중견기업과 소기업에서

25) Yoon(2019)은 주주배정 유상증자시 기존 주주가 취할 수 있는 포지션 세 가지를 분석하였으며 주주가 유상증자에 참여하는 경우의 수익률의 평균이 $-2.12 \%$ 라고 보고한다. 이 경우 수익률은 '상장일종가 $\times(1+$ 배정비율 $)$ 을 '공시일 전일 종가 + 최종발행가격 $\times$ 배정비율'로 나눈 후 1 을 차감하여 계산한다. 이 수익률은 공시일의 주가하락(<표 3>에 의하면 대략 $-12 \%$ 대임)을 반영하므로, 주주가 할인된 가격으로 신주를 매입하더라도 수익률이 마이너스로 계산된다. Yoon(2019)의 ret3은 주주가 공시일을 기준으로 유상증자에 참여하는 경우의 수익률인 반면에, 본 논문의 ret1은 권리락일 중심으로 비주주가 권리부가격에 매입하고 권리락가격에 매도한 후 유상증자에 참여하는 경우의 수익률이다. 
주가조정이 비효율적으로 이루어짐에 따라(특히 소기업인 Q4의 경우 비효율성이 심각함) 이를 이용한 투자전략이 가능함을 보여준다.26)

\section{〈표 12〉 쿼타일별 투자수익률 추정}

투자수익률 ret1은 식 (16)에 의해 계산하며, $O P_{0}$ 는 권리락일의 시가이고 $R P$ 는 기준가격이다. 쿼타일 (quartile)은 신주인수권가치의 상대적 크기인 $P R V / C P_{-1}$ 의 크기를 기준으로 구분한다. *, **, ***는 각각 $10 \%, 5 \%, 1 \%$ 수준에서 통계적으로 유의함을 의미한다. 중앙값에 대해서는 Wilcoxon signed rank test를 적용한다.

패널 A: 쿼타일별 ret1

\begin{tabular}{|c|c|c|c|c|c|c|}
\hline & & \multirow{2}{*}{ 전체 } & \multicolumn{4}{|c|}{ 그룹별 } \\
\hline & & & Q1 & Q2 & Q3 & Q4 \\
\hline$R P / O P_{0}$ & & $0.9613^{* * *}$ & $0.9887^{* * *}$ & $0.9732^{* * * *}$ & $0.9600^{* * * *}$ & $0.9231^{* * *}$ \\
\hline & 평균 & $0.0259^{* * *}$ & 0.0061 & $0.0180^{* * * *}$ & $0.0221^{* * *}$ & $0.0577^{* * *}$ \\
\hline retl & 중앙값 & $0.0052^{* * *}$ & 0.0006 & $0.0121^{* *}$ & $0.0072^{* *}$ & $0.0085^{* *}$ \\
\hline
\end{tabular}

패널 B: 쿼타일별 발행내역

\begin{tabular}{lrrrrr}
\hline & \multirow{2}{*}{ 전체 } & \multicolumn{4}{c}{ 그룹별 } \\
\cline { 3 - 6 } & & $\mathrm{Q} 1$ & $\mathrm{Q} 2$ & $\mathrm{Q} 3$ & $\mathrm{Q} 4$ \\
\hline 총자산(억원) & 3,845 & 7,204 & 3,546 & 3,692 & 940 \\
조달금액(억원) & 299 & 393 & 285 & 323 & 196 \\
할인율(\%) & 26 & 23 & 27 & 28 & 28 \\
배정비율(\%) & 66 & 33 & 37 & 48 & 146 \\
\hline
\end{tabular}

\section{5. 결론}

본 연구는 2004년부터 2016년까지 공시된 주주배정 유상증자 618건(코스피 132건, 코스닥 486건)을 대상으로 권리락일의 주가조정을 분석한다. 거래소는 권리락일에 주가조정이 효율적 으로 이루어지도록 전일에 기준가격을 공시하지만, 본 연구는 시장에서 주가조정이 비효율적으로 이루어지고 있는 증거를 제시한다.

중요한 분석 결과를 정리하면 다음과 같다. 첫째, 권리락일에 신주인수권의 가치만큼 주가 조정이 발생한다면 권리락시가가 기준가격과 동일해야 하는데, 분석 결과 권리락시가를 기준 가격으로 나눈 비율 $\frac{O P_{0}}{R P}$ 이 1.0424 로 $1 \%$ 신뢰수준에서 1 과 동일함을 기각할 수 있다. 이는 신주인수권의 가치보다 작게 주가조정이 이루어짐을 의미하고 이는 시장이 효율적이지 못한 증거로 해석된다. 과소반영되는 경우 비율이 1 보다 작게 계산되도록 하기 위하여 $\frac{R P}{O P_{0}}$ 를 신주인수권가치 반영비율로 정의하였으며 우리 표본에서 평균 0.9613 이다(이 비율이 1 과

26) 신주인수권가치 대신에 신주인수권가치 반영비율을 이용하여 4개의 쿼타일로 나누고 Q1과 Q4를 비교한 결과(반영비율의 평균은 각각 0.90 과 1.01 임), 주가조정이 효율적으로 이루어지는 $\mathrm{Q} 4$ 는 기업규모가 크고 발행비율이 작으며 ret1이 전혀 유의적이지 않으며 이런 결과는 <표 $12>\mathrm{Q} 1$ 의 결과와 매우 유사하다. 반면에 주가조정이 가장 비효율적으로 이루어지는 Q1은 기업규모가 작고 발행비율이 높으며 투자의 수익률이 매우 크게 계산된다. 
Price Adjustments on Ex-Right Dates in Cases of Right Offerings

동일하면 정확하게 주가조정이 이루어지는 것임). 신주인수권의 가치가 권리락일의 주가에 $96.13 \%$ 반영됨은 신주인수권의 가치가 $3.87 \%$ 과소평가됨을 의미한다.

둘째, 신주인수권의 가치를 기준으로 4 개의 쿼타일(quartile)로 나누어 분석한 결과, 신주 인수권의 가치가 클수록 권리락일에서의 주가조정이 더 작게 이루어지며(즉, 신주인수권가치 반영비율이 감소함), 특히 $\mathrm{Q} 4$ 의 경우 이 비율이 0.9231 이고 1보다 작은 경우는 $97 \%$ 이다. 또한 권리락일에 주가가 덜 하락할수록, 권리락일 이후부터 신주상장일까지의 기간 동안에 주가가 더 많이 하락하는데 이는 주가조정(주가하락)이 지연되는 현상을 의미한다.

셋째, 권리락일에서의 초과수익률은 첫 번째 결과와 일관성있게 $4.24 \%$ 이고 $(\mathrm{t}-\mathrm{value}=16.38)$ 권리락일부터 +3 일까지의 $\mathrm{CAR}(0,3)$ 는 $5.73 \%$ 이다. 특히 Q1과 Q4를 비교하면 권리락일의 초과수익률은 각각 $1.09 \%$ 와 $9.31 \%$ 이고, $\mathrm{CAR}(0,3)$ 도 각각 $2.38 \%$ 와 $13.08 \%$ 이다.

넷째, 신주인수권가치 반영비율이 1 보다 작으므로 거래 전략은 권리부가격에 매입하고 권리락가격에 매도하는 것이다. 투자자가 신주를 배정받으면 투자수익률은 $2.59 \%$ 로 $1 \%$ 수준에서 유의적이고, 신주인수권증서로 매도하면 투자수익률은 유의적이지 않다. 특히 Q4의 경우 신주를 배정받는 거래전략의 수익률은 $5.77 \%$ 이며(51일 기준) 이는 1년 기준으로 $41.30 \%$ 에 이른다. 신주인수권증서를 매도하는 전략은 신주인수권증서의 상장이 법으로 의무화된 2013년 이후 가능한데, 투자수익률이 유의적이지 않은 이유는 Yoon(2019)이 보고하듯이 신주인수권증서의 가격이 시장에서 과소평가되기 때문이다.

다섯째, 개인투자자는 '권리부매도 권리락매수'의 패턴을 보이고 외국인투자자는 '권리부매입 권리락매도'의 패턴을 보인 반면에 기관투자자는 특정한 패턴을 보이지 않는다. 여섯째, 신주 인수권증서의 상장제도는 권리락일 주가조정의 비효율성을 완화하는데(또는 감소시키는데) 기여한다. 즉, 신주인수권증서가 상장되는 유상증자와 상장되지 않은 유상증자를 구분하여 권리락일에서의 신주인수권가치 반영비율을 비교한 결과, 신주인수권증서의 상장이 신주인수권 가치 반영비율을 증가시킴을 보여준다.

권리락일에 주가조정이 이루어질 때, 권리락가격이 권리부가격으로부터 신주인수권의 가치 만큼 충분히 하락하지 않으며 그로 인해 초과수익률이 발생하는 메커니즘은 앵커링 편의로 설명이 가능하다. 앵커링 편의는 의사결정시 앵커라고 불리는 특정 값(본 연구에서는 권리부 가격)에 의해 영향을 받는 심리적 편의이다.

본 연구는 주주배정방식만을 연구 대상으로 권리락일의 주가조정을 최초로 분석하였으며, 권리락일에서의 주가조정이 신주인수권의 가치보다 작게 이루어질 뿐만 아니라 추가적으로 조정이 이루어지는 지연현상이 발생하는 '시장의 비효율성'을 발견한다는 점에서 의의가 있다. 권리락일의 주가조정이 효율적으로 이루어지지 않음으로 인해 거래전략이 가능하며, 특히 신주인수권가치가 큰(다시 말해서 배정비율이 큰) 쿼타일의 경우 주가조정이 매우 비효율적으로 이루어지므로 거래전략으로 보다 높은 수익률을 실현할 수 있다. 또한 신주인수권증서의 상장제도가 권리락일 주가조정에서 나타나는 비효율성을 완화하는 결과도 보고한다. 요약하면, 본 연구는 권리락일 주가조정의 비효율성과 이에 따른 투자기회뿐만 아니라 신주인수권증서의 상장제도가 권리락일 주가조정에 미치는 효과를 최초로 제시한다는 점에서 재무이론에 공헌한다고 사료된다. 
한국증권학회지 제49권 3호 (2020)

\section{References}

Barclay, M. J., C. G. Holderness, and D. P. Sheehan, 2007, Private Placements and Managerial Entrenchment, Journal of Corporate Finance, Vol. 13 (4), pp. 461-484.

Bolognesi E., and A. Gallo, 2013, The Ex-Date Effect of Rights Issues: Evidence from the Italian Stock Market, Applied Financial Economics, Vol. 23, pp. 149-164.

Chae, J., 2005, Trading Volume, Information Asymmetry, and Timing Information, Journal of Finance, Vol. 60, pp. 413-442.

Chang, E., T. Lin, Y. Luo, and J. Ren, 2019, Ex-Day Returns of Stock Distributions: An Anchoring Explanation, Management Science, Vol. 65, pp. 1075-1095.

Chung, H., and Y. Jeong, 2008, Seasoned Equity Offering Announcement and Market Efficiency, The Korean Journal of Financial Management, Vol. 25 (3), pp. 79-109.

Eckbo, B. and R. Masulis, 1995, Seasoned Equity Offerings: A Survey, in Handbook in Operations Research and Management Science Series - Finance Chap. 31 (Eds) R.A. Jarrow, V. Maksimovic and W. T. Ziemba, Elsevier/North-Holland, Amsterdam, pp. 1017-72.

Foster, F. D., and S. Viswanathan, 1995, Can Speculative Trading Explain the Volume-volatility Relation?, Journal of Business and Economic Statistics, Vol. 13, pp. 379-396.

Foster, G., C. Olsen, and T. Shelvin, 1984, Earnings Releases, Anomalies, and the Behavior of Security Returns, Accounting Review, Vol. 59, pp. 574-603.

Goyal, V., C. Hwang, N. Jayaraman, and K. Shastri, 1994, The Ex-Date Impact of Right Offerings: The Evidence from Firms Listed on the Tokyo Stock Exchange, Pacific-Basin Finance Journal, Vol. 2, pp. 277-291.

Hertzel, M., and R. L. Smith, 1993, Market Discounts and Shareholder Gains for Placing Equity Privately, Journal of Finance, Vol. 48, pp. 459-485.

Hwang, S., and W. Shin, 2007, Market Responses and Liquidity Effect to Stock Splits in Korea, The Korean Journal of Financial Management, Vol. 24 (4), pp. 201-232.

Jung, W., K. Jeon, and M. Kim, 2002, Tax Effect Reflected on Ex-Day Stock Price Behavior: Cases of Stock Distributions and Stock Dividends, Korean Accounting Review, Vol. 27 (1), pp. 137-170.

Kang, J. and R. Stulz, 1996, How Different is Japanese Corporate Finance? An Investigation of the Information Content of New Equity Issues, Review of Financial Studies, Vol. 9, pp. 109-139.

Khil, J., and S. Han, 2018, Stock Returns on Ex-Dividend Date: Advance Disclosure and Ordinary Disclosure, Eurasia Study, Vol. 15 (3), pp. 111-128.

Kim, D., and S. Moon, 2010, A Study on the Improvement of Capital Increase through Third-party 
Price Adjustments on Ex-Right Dates in Cases of Right Offerings

Allocation, The Journal of Professional Management, Vol. 13 (1), pp. 77-91.

Kim, E. and A. Purnanandam, 2014, Seasoned Equity Offerings, Corporate Governance, and Investments, Review of Finance, Vol. 18, pp. 1023-1057.

Kim, H., and D. Choi, 2016, A Comparative Study on Ex-Dividend Day Behavior of Stock Prices Before and After the Global Financial Crisis: The Evidence from KOSDAQ Market, Korean Corporation Management Review, Vol. 23 (4), pp. 105-124.

Kim, S., 1997, Market Efficiency Tests of the Ex-Dividend Day Behavior of Stock Prices, The Korean Journal of Finance Association, Vol. 14, pp. 145-170.

Kim, S., and J. Byun, 2016, Seasoned Equity Offerings and Trade of Largest Shareholders, The Korean Journal of Finance Association, Vol. 29(1), pp. 1-35.

Kim, S., K. Park, and C. Jung, 2014, A Study on Secondary Equity Offering Flotation Methods and Forms of Underwriting Agreement, The Korean Journal of Finance Association, Vol. 27 (1), pp. 1-44.

Kim, W., Y. Ko, and S. Wang, 2019, Debt Restructuring through Equity Issues, Journal of Banking and Finance, Vol. 106, pp. 341-356.

Lim, B., and P. Yoon, 2017, Informed Trading Before Seasoned Equity Offerings, Korean Journal of Financial Studies, Vol. 46 (1), pp. 133-157.

Lim, B., S. Lee, and P. Yoon, 2019, The Announcement Effect of Private Placements of Seasoned Equity Offerings, The Korean Journal of Financial Management, Vol. 3 6(1), pp. 151-178.

Maloney, M., and J. Mulherin, 1992, The Effects of Splitting on the Ex: A Microstructure Reconciliation, Financial Management, Vol. 21, pp. 44-59.

McGuinness, P., 2001, Ex-day Effects for Right Issues in Hong Kong, Applied Economics Letters, Vol. 8, pp. 5-7.

Park, C., and S. Park, 2011, Investors' Trading Behavior Comparison on Ex-dividend Day, The Korean Journal of Financial Management, Vol. 28 (4), pp. 57-85.

Tversky, A., and D. Kahneman, 1974, Judgment under Uncertainty: Heuristics and Biases, Science, Vol. 185, pp. 1124-1131.

Woo, C., 1993, The Ex-Dividend Stock Price Behavior: An Empirical Analysis, The Korean Journal of Financial Studies, Vol. 15, pp. 215-241.

Wruck, K. H., 1989, Equity Ownership Concentration and Firm Value: Evidence from Private Equity Financings, Journal of Financial Economics, Vol. 23, pp. 3-27.

Yoon, H., Y. Lee, and K. Park, 2013, Management Performance and Announcement Effect of Seasoned Equity Offering, The Journal of Digital Policy \& Management, Vol. 11 (2), pp. 101-114.

Yoon, P., 2016a, Returns and Discount Rates in General Public Seasoned Equity Offerings, 
한국증권학회지 제49권 3호 (2020)

Korean Journal of Financial Studies, Vol. 45 (1), pp. 89-117.

Yoon, P., 2016b, The Announcement Effect of Seasoned Equity Offerings: A Re-examination, Korean Journal of Financial Studies, Vol. 45 (2), pp. 379-415.

Yoon, P., 2019, Listing of Preemptive Right Certificates and Arbitrage Opportunities, Korean Journal of Financial Studies, Vol. 48 (3), pp. 343-370.

Yoon, P., and B. Lim, 2018, The Effect of Short Sales around Seasoned Equity Offerings on the Offering Price, The Korean Journal of Financial Management, Vol. 35 (2), pp. $1-25$.

Yoon, P., J. Kim, and K. Chung, 1998, The Ex-Dividend-Day Behavior of Stock Prices, Korean Journal of Financial Studies, Vol. 22, pp. 111-137.

Yoon, P., S. Choi, and B. Lim, 2017, Is it Advantageous for Managers to Announce Bad News Outside Trading Hours?, The Korean Journal of Financial Management, Vol. 34 (3), pp. 33-59. 